Universidade de São Paulo

Faculdade de Saúde Pública

\title{
Diferenciais de saúde em áreas urbanas e rurais: cárie dentária e condições gengivais em escolares no Estado de São Paulo.
}

\section{Tatiana Ribeiro de Campos Mello}

Tese apresentada ao programa de pós-graduação da Faculdade de Saúde Pública da Universidade de São Paulo para obtenção do título de Doutor.

Área de concentração: Epidemiologia.

Orientador: Prof. Dr. Eliseu Alves Waldman

Co-orientador: Prof. Dr. José Leopoldo Ferreira Antunes

São Paulo

2006 


\title{
Diferenciais de saúde em áreas urbanas e rurais: cárie dentária e condições gengivais em escolares no Estado de São Paulo.
}

\section{Tatiana Ribeiro de Campos Mello}

\author{
Tese apresentada ao programa de pós-graduação da Faculdade \\ de Saúde Pública da Universidade de São Paulo para obtenção \\ do título de Doutor em Saúde Pública. \\ Área de concentração: Epidemiologia. \\ Orientador: Prof. Dr. Eliseu Alves Waldman \\ Co-orientador: Prof. Dr. José Leopoldo Ferreira Antunes
}

São Paulo 
Dedico esse trabalho e minha vida à minha família

Ao meu pai "Carlito" e minha mãe Regina, por me ensinarem a lição mais importante: que os sonhos são possíveis com coragem para enfrentar a batalha, perseverança para não desistir nas primeiras derrotas e apoio das pessoas que nos amam...

Aos meus irmãos, "Lito" e Aline, por estarem sempre lutando comigo... Ao meu marido, "Mi", onde encontrei o apoio constante, a força e o amor...

Obrigada por serem tão especiais, AMO VOCÊS!!! 


\section{Agradecimentos}

Sempre digo que alguém lá em cima gosta muito de mim, porque no meu caminho aparece muita gente especial, meus anjos da guarda. Obrigada meu Deus!

Ao meu professor e amigo, Prof Dr. José Leopoldo Ferreira Antunes, obrigada por acreditar em mim, estar sempre ao meu lado e por ser tão especial.

Ao meu orientador, Prof Dr. Eliseu Alves Waldman, obrigada por esses quatro anos, não apenas pelos muitos ensinamentos, mas também pela amizade e carinho.

Ao Prof. Dr. Henrique Barros, por me receber na Universidade do Porto, Portugal, possibilitando meu crescimento tanto profissional como pessoal.

A todos os novos amigos conquistados em Portugal, especialmente à Profa. Dra. Carla Lopes e à Lilia Braga. Graças ao imenso coração de vocês eu não me senti tão longe de casa.

A todos os professores e amigos da Faculdade de Saúde Pública, em especial à Daniela Schoeps, Ricardo Malagutti, Carolina Moura, Márcia Crozatti, Patrícia F. Paula, pela amizade e companheirismo.

À Cidinha e à Renilda, pela paciência, generosidade e nova amizade.

Aos amigos das Faculdades Santa Cecília e Metodista: Kátia Andrade, Anderson Mota, Edna Silva, Tania Bighetti, Regina Marques, Douglas Scheider Filho, por me possibilitarem os primeiros passos como professora.

À querida amiga, Tania Bighetti, por todo o carinho e incentivo. 
À Gabriela Byazevic, amiga desde as quadras de vôlei nos jogos da faculdade e principal responsável pela motivação para a conclusão dessa etapa.

Ao idealizador da Associação Odonto-criança, Daniel Korytnicki e todos os voluntários, por me possibilitarem aplicar um pouco dos conhecimentos que adquiri nessa pós-graduação para melhorar a saúde bucal de crianças em comunidades carentes de São Paulo.

Aos meus antigos amigos, em especial à Cynthia Hungria, Anne M Oliveira, Carina Luvizotto e Karina Cardozo, por entenderem as minhas muitas ausências.

À Dona Neusa e Sr Melo por cuidarem do meu amor durante o tempo que estive em Portugal complementando a minha formação.

Aos meus avós, presente fisicamente ou no coração, Antônio e Alice, Edgar e Marisa, por serem o alicerce seguro de uma família feliz. Em especial, ao meu vô “Toninho", por ter despertado em mim o gosto pela leitura e pela busca do conhecimento.

Aos meus tios(as) e primos(as), obrigada pela torcida. À tia Liliane, por ter me dado o melhor presente, minha afilhada, Nathália. À tia Vilma e Adriana por estarem comigo em Portugal

Ao CNPq (Conselho Nacional de Desenvolvimento Científico e Tecnológico) e à CAPES (Coordenação de Aperfeiçoamento de Pessoal de Nível Superior) pelas bolsas de estudo concebidas. 
At razão cardeal de toda superioridade humana é, sem dívida, a vontade. $\theta$ poder nasce do querer. Jempre que o homem aplica a veemência e a perseverante energia de sua alma a um fim, ele vencerá todos os obstáculos e, se não atingir o alvo, pelo menos fará coisas admiráveis." (gosé de Atlencar) 


\section{RESUMO}

Mello TRC. Diferenciais de saúde em áreas urbanas e rurais: prevalência de cárie dentária e condições gengivais no Estado de São Paulo. São Paulo; 2006. [Tese de Doutorado - Faculdade de Saúde Pública da USP]

Objetivos: Estudar os diferenciais entre os indicadores de cárie dentária e alterações gengivais em escolares de áreas urbanas e rurais do Estado de São Paulo. Material e Métodos: Estudo de corte transversal analítico e ecológico foram os dois delineamentos utilizados. A população de estudo foram estudantes de escolas urbanas e rurais do Estado de São Paulo de 5 a 7 e de 10 a 12 anos; a fonte de informação foi o "Levantamento das Condições de Saúde Bucal - Estado de São Paulo, 1998”. Foi estimada a prevalência de cárie dentária (índices ceo-d e CPO-D), de sangramento gengival durante a sondagem e de cálculo dental (índice CPI), para o estudo de associação com características sócio-demográficas dos escolares e indicador de desenvolvimento social (IDH-M) das cidades participantes do levantamento. Foram estimadas as odds ratios ajustadas e não ajustadas, por meio de análise de regressão logística e delineamento de modelos multivariados e multiníveis. O estudo de diferenciais de prevalência entre diferentes regiões do Estado empregou uma classificação de áreas rurais homogêneas pré-existente. Resultados: Os indicadores de saúde bucal tiveram distribuição desigual entre os estratos, indicando pior condição para a população rural. Estudar em áreas rurais, em escolas públicas, ser negro ou pardo e ser do sexo masculino associaram com a manifestação de cárie não tratada e alterações gengivais, ao nível dos indivíduos. No modelo multinível, a presença de flúor na água de abastecimento público, o Índice de Desenvolvimento Humano (IDH-M) e o Índice de Cuidado associaram com as condições de saúde bucal estudadas ao nível das cidades participantes do levantamento. Áreas rurais cujo 
sistema produtivo apresentava maior implementação da economia agro-industrial tiveram os melhores indicadores de saúde bucal. Conclusões: Os escolares de área rural mostraram-se mais vulneráveis para todas as condições de saúde bucal avaliadas. Esses achados devem instruir o serviço de saúde, para a programação de medidas específicas dirigidas a esse segmento.

Palavras chave: cárie dentária; sangramento gengival exploratório; cálculo dental; população rural; saúde bucal; epidemiologia. 


\begin{abstract}
Mello TRC. Diferenciais de saúde em áreas urbanas e rurais: prevalência de cárie dentária e condições gengivais no Estado de São Paulo [Health differentials in rural and urban areas: prevalence of dental caries and gingival status in the State of
\end{abstract} São Paulo]. São Paulo (BR); 2006. [PhD Thesis - Faculdade de Saúde Pública da USP Brazil].

Objectives: To assess differentials of prevalence of dental caries and gingival status in schoolchildren from rural and urban areas of the State of São Paulo. Material and Methods: The study population comprised schoolchildren aged 5 to 7 and 10 to 12 years old; the source of information was the "Survey of Oral Health Status - State of São Paulo, 1998". The prevalence of dental caries (dmft and DMFT indices), gingival bleeding on probing and dental calculus (CPI index) were assessed for the appraisal of association with socio-demographic characteristics of schoolchildren and indices of social development of participating towns. The estimation of adjusted and non-adjusted odds ratios used logistic regression analysis, and the fitting of multivariate multilevel models. The study of prevalence differentials among regions of the State used a previous classification of homogeneous rural areas. Results: Indices of oral health had an unequal distribution among strata, indicating a poorer profile for rural population. Studying in rural areas, in public schools, being black and being a boy associated with the odds of presenting untreated dental caries and gingival status at the individual level. Fluoride addition to tap water and the human development index associated with these outcomes at the town level. Rural areas whose productive system presented enhancements associated with the agro-industry had an improved profile of oral health. Conclusion: Schoolchildren in rural areas had a poorer profile for all outcomes of oral health. These findings should instruct health services for programming specific interventions aimed at this stratum. 
Key words: dental caries; gingival bleeding on probing; dental calculus; rural population; oral health; epidemiology. 


\section{ÍNDICE}

1. Introdução 1

2. Revisão de literatura 4

2.1. Cárie dentária e fatores associados $\quad 6$

2.2. Instrumentos de medida do ataque de cárie dentária $\quad 7$

$\begin{array}{ll}\text { 2.3. Condições gengivais e fatores associados } & 7\end{array}$

2.4. Instrumentos de medida das condições gengivais 9

2.5. Cárie dentária em áreas rurais 10

2.6. Condições gengivais em áreas rurais 13

2.7. Atenção à saúde bucal das populações rurais brasileiras 15

2.8. A área rural do Estado de São Paulo 17

3. Justificativa 20

4. Objetivos 22

4.1 Objetivo geral 22

$\begin{array}{ll}4.2 \text { Objetivos específicos } & 22\end{array}$

5. Material e métodos 23

$\begin{array}{ll}5.1 \text { Desenho do estudo } & 23\end{array}$

$\begin{array}{ll}5.2 \text { Caracterização da área de estudo } & 23\end{array}$

$\begin{array}{ll}5.3 \text { População de estudo } & 24\end{array}$

5.4 Definição de caso 25

5.4.1. Cárie dentária 25

5.4.2. Alterações gengivais 25

5.5. Amostra 25

$\begin{array}{ll}5.6 \text { Fonte de dados } & 27\end{array}$

5.6.1. Levantamento epidemiológico de saúde bucal (USP 1999) 27

5.6.2. Dados socioeconômicos municipais 28

$\begin{array}{ll}\text { 5.7. Variáveis de estudo } & 28\end{array}$

5.8. Análise 30

5.8.1. Cálculo dos indicadores de saúde bucal 30

5.8.1.1. Indicador de cárie dentária 30 
5.8.2. Descrição da distribuição dos agravos nas áreas urbana e rural 32

5.8.3. Análise multinível 33

5.8.4. Análise espacial segundo características do desenvolvimento rural 34

5.9. Aspectos éticos 37

6. Resultados 38

6.1. Descrição da população estudada 38

6.2. Cárie dentária 41

6.3. Condições gengivais 47

6.3.1. Presença de sangramento gengival à sondagem 47

6.3.2. Presença de cálculo dental visível $\quad 54$

6.4. Indicadores de saúde bucal em áreas rurais homogêneas 61

6.4.1. Cárie dentária em áreas rurais homogêneas 61

6.4.2. Condições gengivais em áreas rurais homogêneas 64

6.4.2.1. Sangramento gengival à sondagem 64

6.4.2.2. Cálculo dental em áreas rurais homogêneas 66

7. Discussão $\quad 69$

8. Conclusões $\quad 86$

9. Referências

10 Anexo 103 


\section{Lista de Tabelas}

Tabela 6.1.1 Distribuição das crianças examinadas para os indicadores de saúde bucal na dentição decídua, segundo a idade, em áreas urbanas e rurais, estado de São Paulo, 1998.

Tabela 6.1.2 Distribuição das crianças examinadas para os indicadores de saúde bucal na dentição permanente, segundo a idade, em áreas urbanas e rurais, Estado de São Paulo, 1998.

Tabela 6.1.3. Distribuição de escolares de 5 a 7 anos de áreas urbanas e rurais, segundo as características sócio-demográficas, estado de São Paulo, 1998.

Tabela 6.1.4. Distribuição de escolares de 10 a 12 anos de áreas urbanas e rurais, segundo as características sócio-demográficas, Estado de São Paulo, 1998.

Tabela 6.2.1 Experiência de cárie dentária na dentição decídua, acesso a tratamento odontológico e número de crianças examinadas de 5 a 7 anos, em áreas urbanas e rurais, São Paulo, 1998.

Tabela 6.2.2 Experiência de cárie dentária na dentição permanente, acesso a tratamento odontológico e número de crianças examinadas em áreas urbanas e rurais, São Paulo, 1998.

Tabela 6.2.3. Distribuição de escolares de 5 a 7 anos de áreas urbanas e rurais, segundo a prevalência de cárie não tratada $(c \geq 1)$ e características sócio-demográficas, Estado de São Paulo, Brasil, 1998.

Tabela 6.2.4. Distribuição de escolares de 10 a 12 anos de áreas urbanas e 
rurais, segundo a prevalência de cárie não tratada $(C \geq 1)$ e características sócio-demográficas, Estado de São Paulo, Brasil, 1998.

Tabela 6.2.5. Modelo multinível de análise multivariada de regressão logística para a prevalência de cárie não tratada, crianças de 5 a 7 anos de idade, Estado de São Paulo, Brasil, 1998.

Tabela 6.2.6. Modelo multinível de análise multivariada de regressão logística para a prevalência de cárie não tratada, escolares de 10 a 12 anos de idade, Estado de São Paulo, 1998.

Tabela 6.3.1.1. Distribuição dos escolares de 5 a 7 anos de áreas urbanas e rurais, segundo a prevalência de sangramento gengival à sondagem $(\mathrm{CPI} \geq 1)$, Estado de São Paulo, Brasil, 1998.

Tabela 6.3.1.2. Distribuição dos escolares de 10 a 12 anos de áreas urbanas e rurais, segundo a prevalência de sangramento gengival à sondagem (CPI $\geq 1)$, Estado de São Paulo, Brasil, 1998.

Tabela 6.3.1.3. Distribuição de escolares de 5 a 7 anos de áreas urbanas e rurais, segundo a prevalência de sangramento gengival à sondagem $(\mathrm{CPI} \geq 1)$ e características sócio-demográficas, Estado de São Paulo, Brasil, 1998.

Tabela 6.3.1.4. Distribuição de escolares de 10 a 12 anos de áreas urbanas e rurais, segundo a prevalência de sangramento gengival à sondagem $(\mathrm{CPI} \geq 1)$ e características sócio-demográficas, Estado de São Paulo, Brasil, 1998.

Tabela 6.3.1.5. Modelo multinível de análise multivariada de regressão logística para a prevalência de sangramento gengival durante sondagem, crianças de 5 a 7 anos de idade, Estado de São Paulo, 1998.

Tabela 6.3.1.6. Modelo multinível de análise multivariada de regressão 
logística para a prevalência de sangramento gengival durante sondagem, crianças de 10 a 12 anos de idade, Estado de São Paulo, 1998.

Tabela 6.3.2.1 Número e porcentagem de presença $(\mathrm{CPI}=2)$ ou não $(\mathrm{CPI} \leq$

1) de cálculo dentário visível em escolares de 5 a 7 anos de áreas urbanas e rurais, Estado de São Paulo, 1998.

Tabela 6.3.2.2. Número e porcentagem de presença $(\mathrm{CPI}=2)$ ou não $(\mathrm{CPI} \leq$

1) de cálculo dentário visível em escolares de 10 a 12 anos de áreas urbanas e rurais, Estado de São Paulo, 1998.

Tabela 6.3.2.3 Distribuição de escolares de 5 a 7 anos de áreas urbanas e rurais, segundo a prevalência de cálculo dental visível $(\mathrm{CPI}=2)$ e características sócio-demográficas, Estado de São Paulo, Brasil, 1998.

Tabela 6.3.2.4. Distribuição de escolares de 10 a 12 anos de áreas urbanas e rurais, segundo a prevalência de cálculo dental visível $(\mathrm{CPI}=2)$ e características sócio-demográficas, Estado de São Paulo, Brasil, 1998.

Tabela 6.3.2.5 Análise multivariada de regressão logística para a 59 prevalência de cálculo dental, crianças de 5 a 7 anos de idade, Estado de São Paulo, 1998.

Tabela 6.3.2.6. Modelo multinível de análise multivariada de regressão 60 logística para a prevalência de cálculo dental, crianças de 10 a 12 anos de idade, São Paulo, 1998.

Tabela 6.4.1.1 Áreas rurais homogêneas de acordo com o índice de cárie (ceo-d), índice de cuidado (IC) e a prevalência de cárie não tratada na dentição decídua. São Paulo, 1998. 
Tabela 6.4.1.2 Áreas rurais homogêneas de acordo com o índice de cárie (CPO-D), índice de cuidado (IC) e a prevalência de cárie não tratada na dentição permanente. São Paulo, 1998.

Tabela 6.4.1.3 Razão dos indicadores de saúde bucal utilizando a classe 10 como referência. São Paulo, 1998

Tabela 6.4.2.1.1 Áreas rurais homogêneas de acordo com a presença de 65 sangramento gengival à sondagem $(\mathrm{CPI}=1)$ na dentição decídua. São Paulo, 1998.

Tabela 6.4.2.1.2 Áreas rurais homogêneas de acordo com a presença de 66 sangramento gengival a sondagem $(\mathrm{CPI}=1)$ na dentição permanente. São Paulo, 1998.

Tabela 6.4.2.2.1. Áreas rurais homogêneas de acordo com a presença de cálculo dental visível (CPI=2) na dentição decídua. São Paulo, 1998.

Tabela 6.4.2.2.2 Áreas rurais homogêneas de acordo com a presença de 68 cálculo dental visível (CPI=2) na dentição permanente. São Paulo, 1998. 


\section{INTRODUÇÃO}

A saúde bucal é parte integrante e essencial da saúde geral e, sendo assim, é um fator determinante para a qualidade de vida. A cárie dentária e a doença periodontal são os principais agravos à saúde bucal. São considerados problemas de saúde pública porque tem impacto relevante no indivíduo e na comunidade, possuem elevada prevalência e podem ser efetivamente prevenidos e controlados pela ação conjunta da comunidade, profissionais de saúde e indivíduos (GELBIER et al. 2002).

A cárie dentária, o agravo à saúde bucal mais prevalente principalmente em crianças e adolescentes, pode ocasionar sofrimento físico e psíquico, como dor, dificuldade mastigatória, constrangimento para sorrir e embaraço com a aparência. Como conseqüência, pode afetar a auto-estima e levar à diminuição do contato social. (LEAKE et al. 1990; PETERSEN 2003). Na sociedade ocidental contemporânea a aparência bucal é considerada um componente importante da estética pessoal, influenciando, de certa forma, especialmente entre os jovens, a melhor socialização das pessoas, facilitando inclusive o acesso a atividades profissionais que pressuponham maior exposição ao público (JENNY e PROSHEK 1986; FISKE e WATERS 1990).

Além disso, tem sido considerada a hipótese de que uma infecção dentária não tratada pode participar da etiologia de doenças potencialmente letais como a endocardite bacteriana e septicemia (GELBIER et al. 2002).

Nos últimos anos, levantamentos epidemiológicos de saúde bucal têm indicado tendência de declínio na prevalência de cárie em muitos países do mundo. 
Entre 1969 e 1997, a prevalência de cárie nos países desenvolvidos diminuiu de patamares muito elevados para um nível aceito como baixo. De acordo com o banco de dados de saúde bucal da Organização Mundial da Saúde, em 1980, apresentavam CPO-D menor que três, aos 12 anos, 51\% de 173 países. No ano 2000, de 184 países 68\% apresentavam essa condição (PETERSEN 2003). Em revisão sistemática da literatura abrangendo o período de 1970 a 2000, BÖNECKER e CLEATON JONES (2003) observaram que em países da América Latina e Caribe, incluindo o Brasil, a prevalência de cárie nos grupos etários de 5 a 6 e de 11 a 12 anos está diminuindo ou permanecendo estável. NARVAI et al. (1999) concluíram que a fluoretação da água de abastecimento público, a adição de flúor aos dentifrícios e a descentralização do sistema de saúde foram fatores importantes para o declínio na experiência de cárie em escolares brasileiros.

Entretanto, a redução da prevalência de cárie dentária em diversas partes do mundo foi acompanhada pelo fenômeno conhecido como polarização da doença, caracterizado pela concentração de índices de cárie mais elevados em grupos populacionais submetidos à privação dentro de um mesmo país ou região (ANTUNES et al. 2002).

Outro agravo importante, entre aqueles que interferem na saúde bucal são as alterações gengivais, pois apresentam uma larga distribuição em todo o mundo e afetam adultos e crianças, sendo alta a prevalência da gengivite em todas as comunidades (MARCANTONI JÚNIOR e SANTOS 1998). Entretanto, fatores socioeconômicos e comportamentais, principalmente a falta de acesso à informação e assistência odontológica aumentam o risco da criança desenvolver o agravo. GARCIA-GODOY et al. (1986) observaram que 93\% das crianças de escolas 
públicas da República Dominicana necessitavam de algum tipo de tratamento periodontal.

Uma das principais aplicações da epidemiologia em saúde pública é a identificação de grupos e fatores de risco com o objetivo de subsidiar os gestores de saúde na elaboração de estratégias de controle de doenças e promoção da saúde. Para a melhor compreensão das mudanças que assistimos, nas últimas décadas, nos padrões da saúde bucal em comunidades de diferentes níveis de desenvolvimento é indispensável uma revisão dos fatores intervenientes nesse processo. 


\section{REVISÃO DA LITERATURA}

A revisão de literatura foi organizada de modo a permitir ao leitor a compreensão de aspectos importantes da caracterização epidemiológica da cárie dentária e das condições gengivais.

Muitos estudos efetuados tanto no Brasil como em outros países, descrevem a situação de saúde bucal de populações residentes em áreas urbanas, porém poucos abordam a mesma situação em regiões rurais. Dessa maneira, optou-se em focalizar na revisão da literatura as condições de saúde bucal de populações rurais comparando-as com as respectivas áreas urbanas.

Primeiramente, definem-se os agravos estudados e os instrumentos de medida utilizados. A partir dessas informações descrevem-se a magnitude desses agravos à saúde bucal em populações residentes em áreas rurais, os diferenciais encontrados na comparação com as respectivas áreas urbanas e relatam-se historicamente as políticas públicas brasileiras e o desenvolvimento da área rural paulista.

\subsection{Cárie dentária e fatores associados}

A cárie dentária é uma doença infecciosa transmissível multifatorial, sendo o resultado de um processo dinâmico que ocorre nos depósitos microbianos que formam a placa bacteriana na superfície do dente e que resulta em distúrbio do 
equilíbrio entre a substância do dente e o fluído da placa aderida. Com o decorrer do tempo, ocorre a perda de mineral na superfície do dente ocasionando uma cavidade, sinal da doença (THYLSTRUP 2001).

De acordo com o Diagrama de Keyes (1960), a ocorrência de cárie se deve a fatores relativos ao hospedeiro (meio bucal), substrato (dieta) e microorganismo. Newbrun (1978) acrescentou que esses fatores precisam interagir no tempo. Segundo estudos mais recentes, também devem ser consideradas outras variáveis que interferem nesse processo, como sexo, idade, distribuição temporal e geográfica, além de variáveis socioeconômicas, culturais e comportamentais (FREITAS 2001). Sendo assim, a prevalência de cárie poderia variar conforme a cultura da região estudada, grau de escolaridade das pessoas afetadas, seu padrão alimentar, de moradia, acesso a serviços odontológicos, entre outros (PINTO 2000).

DIEHNELT e KIYAK (2001) estudaram os fatores socioeconômicos que influenciam na prevalência de cárie em diversas regiões do mundo. Países em desenvolvimento com produto interno bruto relativamente elevado e que incorporaram hábitos alimentares que incluem o consumo de produtos industrializados cariogênicos, apresentaram maior prevalência de cárie que regiões desenvolvidas e países em desenvolvimento com pequeno produto interno bruto. A baixa prevalência de cárie, nesse último, estaria associada à falta de acesso a produtos alimentares cariogênicos e, nos países desenvolvidos, a melhores condições de vida e acesso a serviços preventivos e assistenciais de saúde. 


\subsection{Instrumentos de medida do ataque de cárie dentária}

Ao longo do tempo, diferentes instrumentos foram utilizados para medir o ataque de cárie dentária. No início do século XX, KLEIN e PALMER (1940) introduziram o índice CPO, amplamente utilizado até os dias atuais. Para medir a experiência de cárie dentária na dentição permanente, registra-se o número de dentes “cariados" (C), “perdidos" (P) e "obturados" (O) em cada indivíduo. O valor resultante da somatória do número de dentes permanentes atacados por cárie configura o índice (CPO-D). Para a dentição decídua o índice correspondente é o ceo-d, que resulta da somatória dos dentes decíduos "cariados" (c), "extraídos" (e) e obturados (o) (GRUEBELL 1944).

No decorrer do tempo, diferentes metodologias foram empregadas para efetuar as observações que resultara no índice CPO. Com o objetivo de diminuir a influência de interpretações clínicas subjetivas introduzidas pelos observadores no cálculo desse índice, os critérios de diagnóstico da cárie e outras indicações metodológicas foram consolidados em um manual de procedimentos técnicos padronizados pela Organização Mundial de Saúde. De acordo com essa padronização o dente é considerado cariado quando apresenta cavidade evidente em superfície lisa ou fissura, esmalte socavado ou um amolecimento detectável do assoalho ou das paredes. O dente com restauração ou com selante, mas que esteja também cariado, deve ser incluído nessa categoria. O índice mede também a experiência prévia de cárie, pois inclui os dentes que receberam restauração dental ou foram extraídos devido à cárie. O dente é considerado obturado quando uma ou mais restaurações estão presentes. O dente que foi extraído devido à cárie é considerado perdido (WHO 1997). 
De acordo com PETERSEN (2003) o índice CPO-D, aos 12 anos, pode ser classificado como:

Quadro 2.2.1 Classificação do índice CPO-D aos 12 anos.

\begin{tabular}{|c|c|c|c|}
\hline Muito baixo & Baixo & Moderado & Alto \\
\hline$<1,2$ & $1,2-2,6$ & $2,7-4,4$ & $>4,4$ \\
\hline
\end{tabular}

Apesar dessa classificação ser contraditória ao aceitar a existência da cárie dentária, apresenta-se esse quadro para facilitar a compreensão dos valores do índice CPO-D.

O Índice de Cuidado (IC) (Walsh 1970) pode ser calculado partir dos dados coletados para os índices ceo-d e CPO-D. Esse instrumento é amplamento utilizado para estudos comparativos de avaliação de programas de atendimento odontológico.

O exame para a detecção da cárie dentária em levantamentos epidemiológicos pode subestimar a sua real existência, resultados falso-negativos podem surgir principalmente em duas circunstâncias: i) presença de cavidades de cárie proximais por serem de difícil identificação; ii) cárie em estágio inicial de desmineralização, sem cavitação, não é considerada como presente. Sendo uma medição dicotômica, cárie ausente ou presente, perde-se a informação da gravidade da lesão.

\subsection{Condições gengivais e fatores associados}

A placa bacteriana é considerada fator etiológico dos agravos gengivais. Secreções tóxicas das bactérias acumuladas na placa podem causar gengivites, cujos sinais clínicos podem ser observados após duas ou três semanas. São basicamente: edema, alteração de cor, aumento do fluido sulcular, resistência à sondagem reduzida 
e presença de sangramento à sondagem ou quando os dentes são escovados (LÖE et al. 1965; BROWN e LOË 2000).

Quando existem sinais clínicos de inflamação restritos à gengiva, tal condição é denominada gengivite. Mas, se a inflamação atinge os tecidos de sustentação (osso alveolar, ligamento periodontal e cemento), esta condição é denominada periodontite. A inflamação pode ser restrita a uma única região da boca ou ser generalizada, atingindo toda, ou quase toda a boca. Nem sempre a gengivite evolui para periodontite, mas é freqüente que algumas periodontites crônicas sejam precedidas por gengivites (BROWN e LOË 2000; BASSANI e LUNARDELLI 2006).

O aumento da idade está diretamente relacionado com o aumento do risco de desenvolver doenças periodontais. Entretanto, o processo de destruição periodontal pode apresentar seu início na infância e a gengivite instalada na criança constitui o primeiro fator que poderá levar à destruição dos tecidos periodontais de sustentação e consequentemente o risco de perda do elemento dental (BASSANI e LUNARDELLI 2006).

A mineralização da placa bacteriana é denominada cálculo dental. Sua presença funciona como fator irritante local para a gengiva, contribui para a retenção de placa bacteriana e facilita a progressão de gengivites e periodontites.

Fatores socioeconômicos e comportamentais podem influenciar a prevalência e severidade dos agravos gengivais. Hábitos adequados de higiene bucal e utilização regular de serviços odontológicos podem remover a placa dental e prevenir tanto gengivites como presença de cálculo. A presença destas condições pode ser considerada como indicação de condição bucal não saudável e risco para o 
desenvolvimento de cárie dentária. GARMONAL et al. (1998) observaram que indivíduos que possuíam condição socioeconômica mais elevada apresentavam menor prevalência e severidade de doenças gengivais, quando comparados com indivíduos com médio ou baixo nível socioeconômico.

\subsection{Instrumentos de medida das condições gengivais}

Em 1987, a Organização Mundial de Saúde (OMS) apresentou o Índice Periodontal Comunitário (Community Periodontal Index of Treatmente Needs CPITN) para padronizar os levantamentos epidemiológicos das condições periodontais em diferentes populações. O CPITN registra a condição periodontal e é complementado por indicativos de necessidades de tratamento, visando propiciar o planejamento do tratamento dos indivíduos examinados.

O Índice Periodontal Comunitário (Community Periodontal Index - CPI) foi adotado pela OMS a partir de 1997. Representa uma derivação do índice anterior, porém sem referência às necessidades de tratamento tornando-o mais simples de ser utilizado. Os dentes são agrupados em sextantes e alguns dentes índice são examinados em cada sextante, sendo anotada a pior condição encontrada. Em indivíduos menores de 15 anos são examinados os seguintes dentes: primeiros molares superiores direito e esquerdo, incisivo superior direito, incisivo inferior esquerdo e primeiros molares inferiores direito e esquerdo. Apenas o sangramento gengival durante a sondagem $(\mathrm{CPI}=1)$ e a presença cálculo $(\mathrm{CPI}=2)$ são registrados (WHO 1997). 


\subsection{Cárie dentária em áreas rurais}

A maioria dos estudos internacionais de prevalência de cárie dentária em populações residentes em áreas consideradas rurais foi desenvolvida no continente africano. Em um estudo realizado em 1985, observou-se que $20,9 \%$ das crianças de 12 anos da área rural de Zimbábue apresentavam cárie dentária sem tratamento e índice CPO-D de 0,49 (CHIRONGA e MANJI 1989). Entre 1991 e 1992, SATHANANTHAN et al. (1996) realizaram estudo em uma província rural no sudoeste de Zimbábue visando analisar a prevalência de cárie dentária, o acesso à água fluoretada e hábitos de higiene bucal dos escolares de 5-6 e 12 anos. Aos 5-6 anos a prevalência de cárie foi de $25,2 \%$ e ceo-d de 0,6 . Aos 12 anos a prevalência foi de 19,8\% com CPO-D de 0,3. Os autores atribuíram essa baixa prevalência encontrada a dois fatores: 1) aproximadamente $40 \%$ das escolas incluídas no estudo tinham acesso à água com uma concentração de flúor de $0,8 \mathrm{ppm}$, considerado o nível ideal para países tropicais; 2) a província estudada, do Zimbábue, é aquela menos urbanizada da África, permitindo que seus moradores mantenham hábitos alimentares mais saudáveis.

Um dos primeiros estudos sobre prevalência de cárie dentária em população residente em área rural brasileira foi desenvolvido por HILLE (1976) em uma fazenda de Londrina, Paraná. Seu objetivo era contribuir para a elaboração de um plano de saúde bucal aplicado a áreas rurais de maior densidade demográfica, uma vez que grande parte da população rural, no período, era constituída por trabalhadores agrícolas que viviam concentrados em grandes fazendas, residindo em colônias. Através da realização de levantamento epidemiológico de saúde bucal, o 
autor identificou elevada prevalência de cárie dentária e necessidade de tratamento odontológico nos moradores da fazenda onde o estudo foi realizado.

Estudos semelhantes foram realizados em diferentes áreas rurais do Brasil. A maioria dos levantamentos possui como idade mínima seis anos e utiliza o índice CPO-D, medindo apenas a experiência de cárie em dentes permanentes. Na zona rural de Uberlândia, MG, MARQUES et al. (1986) encontraram o índice CPO-D médio aos seis anos de 2,6 que pode ser considerado bastante alto considerando que as crianças dessa faixa etária apresentam poucos dentes permanentes. Aos 12 anos o valor do CPO-D encontrado nos escolares rurais brasileiros apresenta uma grande variação, desde 2,5 em áreas rurais da Paraíba onde havia uma concentração natural de flúor na água $(0,7-1,0$ ppm) (SAMPAIO et al. 2000) até CPO-D 15,5 em escolares de 12 anos de Uberlândia que não tinham acesso à rede municipal de abastecimento de água fluoretada, o que indica uma prevalência de cárie muito elevada (MARQUES et al. 1986; DINI et al. 1993; FURTADO et al. 1999).

Estudos na África (PETERSEN e MZEE 1998; MOALIC et al. 1999; BLAY et al. 2000); no Iraque (JAMEL et al. 1997); na América Central (ALONGE e NAREDRAN 1999) e Austrália (BRENNAN et al. 2000) observaram uma menor prevalência de cárie dentária em áreas rurais que nas respectivas áreas urbanas, situação oposta à encontrada em áreas rurais brasileiras (MELLO e ANTUNES 2004). No entanto, essas regiões foram descritas pelos autores como isoladas das regiões urbanas mais próximas mantendo hábitos peculiares e intensa privação social, em marcante contraste com a área rural estudada por MELLO e ANTUNES (2004) onde pequenos distritos rurais foram criados para suprir as carências inerentes 
à distância da área urbana, e nesses distritos são encontrados pontos de comércio, escolas e, em alguns, o posto de saúde.

O consumo de alimentos contendo açúcar, principalmente no que diz respeito à freqüência de sua ingestão, é extensamente reconhecido como importante fator de risco da cárie dentária. Diversos autores observaram, através do uso de questionários, que os moradores de áreas rurais apresentavam baixo consumo de açúcar (DINI et al. 1993; JAMEL et al. 1997; BLAY et al. 2000; IRIGOYEN et al. 2000; SAMPAIO et al. 2000; MELLO e ANTUNES 2004). Estudos na África (PETERSON e MZEE 1998; MOALIC et al. 1999; BLAY et al. 2000); no Iraque (JAMEL et al. 1997); na América Central (ALONGE e NAREDRAN 1999) e Austrália (BRENNAN et al. 2000) também apontaram que populações em áreas rurais possuíam menos acesso a produtos industrializados açucarados, sugerindo que esse fator tenha contribuído para o registro de uma prevalência de cáries menos elevada que a das respectivas populações urbanas.

De acordo com SAMPAIO et al. (2000), no entanto, a dieta está mudando nas áreas rurais do Brasil, em função do maior acesso aos produtos industrializados e ao açúcar, o que pode provocar um aumento na prevalência de cárie dentária dessas populações.

O acesso a serviços de saúde preventivos e assistenciais é outro fator associado com maior ou menor prevalência de cárie dentária. A maior dificuldade de acesso a serviços de saúde bucal dos residentes em áreas rurais foi relatada em diversos estudos de áreas rurais de diferentes países (HILLE 1976; CANTON et al. 1985; MARQUES et al. 1986; MANJI et al. 1988; DINI et al. 1993; SATHANANTHAN et al. 1996; NTABAYE et al. 1998; ALONGE e NAREDRAN 
1999; ATTIN et al. 1999; BRENNAN et al. 2000; BRINDLE et al. 2000; CROWLEY et al. 2000; IRIGOYEN et al. 2000; MATTILA et al. 2000; TEIXEIRA et al. 2000). O número de dentes com cavidades evidentes decorrentes de cárie sem tratamento foi elevado em áreas rurais brasileiras e africanas, indicando baixa cobertura dos serviços odontológicos (DINI et al. 1993; SATHANANTHAN et al. 1996; BRINDLE et al. 2000; MELLO e ANTUNES 2004).

Consumo elevado de produtos açucarados, condições de privação social e dificuldade de acesso a serviços odontológicos preventivos e assistenciais são fatores de risco para a cárie dentária (PERES et al. 2003). Nesse sentido, a prevalência mais elevada de cárie encontrada em diferentes áreas rurais deve ser considerada como associada à desinformação sobre saúde bucal, dificuldade de acesso ao tratamento odontológico e a fatores econômicos, condições comuns a grupos de população rural de diferentes países e regiões brasileiras.

\subsection{Condições gengivais em áreas rurais}

Os estudos epidemiológicos sobre a saúde bucal de populações rurais são escassos, sendo ainda mais raros os que abordam doenças gengivais em população infantil.

BRINDLE et al (2000) observaram em uma comunidade rural da África do Sul que apenas $1 \%$ dos escolares apresentava condição gengival sadia. Sangramento gengival foi encontrado em $68 \%$ das crianças de 5 anos e aos 12 anos $80 \%$ apresentavam sangramento ou cálculo dental. Situação semelhante à encontrada por PETERSEN e MZEE (1998) em comunidades rurais de duas ilhas situadas a 40km da costa leste da África, no oceano índico. 
Níveis elevados de prevalência de sangramento gengival e necessidades de tratamento odontológico também foram relatados para populações rurais no Brasil. MARCANTONIO JUNIOR e SANTOS (1998) observaram na área rural de Fernandópolis (município da região noroeste do Estado de São Paulo) uma alta prevalência de sangramento gengival e cálculo nas faixas de 6 a 7 e de 8 a 9 anos, com apenas duas crianças apresentando todos os sextantes saudáveis. Na faixa etária dos 10 a 14 anos; todas as crianças do estudo apresentaram algum tipo de alteração gengival.

No distrito rural de Campo Redondo, cidade de Itamonte, em Minas Gerais, entre as crianças de 0 a 5 anos $45 \%$ necessitavam de instruções de higiene bucal, enquanto que, no grupo etário de 6 a 12 anos essa proporção atingia 93\%, com 34\% das crianças necessitando ainda de raspagem e profilaxia dos dentes (PALLOS et al. 2005).

A dificuldade de acesso da população residente em áreas rurais a informações sobre saúde bucal e a tratamentos odontológicos preventivos e curativos é citada como um dos fatores responsáveis pela alta prevalência e severidade de doenças gengivais em escolares brasileiros (MARCANTONIO JUNIOR e SANTOS 1998; PALLOS et al. 2005) e africanos (PETERSEN e MZEE 1998; BRINDLE et al 2000).

Em Zanzibar, apenas 52\% dos escolares de áreas rurais limpam seus dentes ao menos uma vez ao dia e somente $8 \%$ tiveram acesso a tratamento odontológico. $\mathrm{O}$ uso de dentifrício e escova dental foi relatado por $13 \%$ enquanto $72 \%$ utilizavam uma espécie de graveto retirado de árvores nativas para realizar a higiene dos dentes (PETERSEN e MZEE 1998). 
Insuficiente informação sobre saúde bucal, dificuldades de acesso ao tratamento odontológico e precárias condições socioeconômicas, condições comuns a grupos de população rural de diferentes países e de regiões brasileiras, são fatores de risco para ambas as dimensões da saúde bucal selecionadas para esse estudo: cárie dentária e condição gengival (MARCANTONIO JUNIOR e SANTOS 1998; PETERSEN e MZEE 1998; BRINDLE et al. 2000; SAMPAIO et al. 2000).

\subsection{Atenção à saúde bucal das populações rurais brasileiras}

Do ponto de vista econômico, político, social e cultural, o Brasil sempre teve uma importante base rural. Apesar disso, até meados do século XX, foi deficitária a atenção à saúde dos trabalhadores rurais. CARNEIRO et al. (1998) revisaram a literatura sobre políticas de saúde para a população rural brasileira, observando que a exclusão dos trabalhadores do campo caracterizava-se, entre outros fatores, pela falta de acesso aos serviços de saúde, como traço sempre presente na história do país.

Segundo PINTO (1977), somente em 1951 os trabalhadores do campo, em áreas distantes do Norte e Nordeste do Brasil, passaram a ter acesso a assistência odontológica, a partir da incorporação da Seção de Odontologia no Serviço Especial de Saúde Pública (SESP), em um convênio firmado entre os governos brasileiro e americano, através da Fundação Rockfeller. Foi, no entanto, somente com a criação de postos de atendimento permanente em pequenas cidades do interior, que essa assistência atingiu de modo mais efetivo a área rural, o que só ocorreu a partir do término do convênio com a Fundação Rockfeller e a incorporação do Serviço Especial de Saúde Pública (SESP) pelo Ministério da Saúde, como Fundação SESP em 1960. 
Apesar de a Fundação SESP ter sido a primeira instituição a oferecer atendimento odontológico à população residente em áreas rurais brasileiras, o acesso ao serviço era restrito às crianças em idade escolar, na forma de "Sistema Incremental", no município que possuísse um posto de atendimento instalado. Dessa maneira, atingia apenas alguns pontos isolados e não atendia às necessidades da maioria dos trabalhadores rurais (PINTO 1977). Sua maior contribuição foi ter realizado campanhas preventivas, valorizando essas iniciativas no âmbito da promoção em saúde, e implantado a fluoretação das águas de abastecimento público, a partir do projeto piloto em Baixo Guandu, ES, 1953. CARNEIRO et al. (1998) salientam que a Fundação SESP induziu uma mudança de paradigma na assistência à zona rural.

Com a posterior incorporação do trabalhador rural brasileiro ao sistema oficial de previdência social, através do FUNRURAL - Fundo de Assistência ao Trabalhador Rural (1968) e da criação do Pro-Rural - Programa de Assistência ao Trabalhador Rural (1971), uma política de assistência odontológica mais efetiva passou a existir para essa população. A partir desse momento, os trabalhadores do campo passaram a ter direito a assistência médica e odontológica, sendo integrados à Previdência Social, o sistema público responsável pela assistência à saúde dos trabalhadores no período.

PINTO (1977), no entanto, sublinhou as precariedades ainda presentes no atendimento odontológico então provido pelo serviço público: os atendimentos eram realizados através da livre demanda; os profissionais de saúde que atendiam essa população recebiam salários baixos e suas condições de trabalho eram precárias; a 
assistência odontológica promovida pelo FUNRURAL era exclusivamente curativa e com grande número de extrações dentárias.

Recentemente, com a Constituição de 1988, foram introduzidas importantes modificações no sistema de saúde do país. Com a criação do Sistema Único de Saúde - SUS (1990) firmou-se o princípio de integralidade no atendimento à saúde, demandando a plena inserção da Odontologia no sistema de atenção à saúde no Brasil. Além disso, foi firmado o princípio de universalidade no atendimento à saúde, o que implica a equivalência de serviços providos para a população residente em áreas urbana e rural, sendo necessárias medidas concretas para que isso de fato ocorra.

\subsection{A área rural do Estado de São Paulo}

De acordo com CHABARIBERY (1999), apesar do Estado de São Paulo possuir a agricultura mais moderna entre os Estados brasileiros, isso não garante homogeneidade entre as áreas rurais dos seus municípios. Há regiões muito desenvolvidas, formando os assim chamados complexos agroindustriais, e áreas de agricultura ainda bastante atrasada, o que, de algum modo, pode influir na distribuição de agravos à saúde. Essas diferenças se devem não apenas à diversidade de recursos naturais de cada município, como também ao processo histórico do desenvolvimento agrícola do Estado.

O cultivo da cana-de-açúcar, entre 1765 e 1851, no chamado quadrilátero do açúcar, abrangendo a região de Piracicaba, Itu, Porto Feliz, São Carlos, Jundiaí, Parnaíba e o litoral, transformou a agricultura paulista à época predominantemente 
de subsistência, permitindo que adquirisse características comerciais (PETRONI 1968).

Até meados do século XIX, a cultura cafeeira ocupava apenas a região do Vale do Paraíba, sendo escoada através de tropas de burros para o porto do Rio de Janeiro (MORSE 1970). Com a construção de uma rede de ferrovias e a entrada, em grande número, de imigrantes europeus e, posteriormente, por asiáticos, a cultura do café pôde se expandir para as regiões norte e oeste do Estado de São Paulo, onde encontrou espaço e condições climáticas favoráveis para uma grande expansão. A produtividade da cultura cafeeira nesse período configurou um novo ciclo de riqueza para o país, enquanto a região do vale do Paraíba entrava em decadência (ANTUNES 1998).

O cultivo do algodão se expandiu a partir de Sorocaba em direção ao norte do Estado, de Campinas a Jaboticabal, ao sul (Itapetininga), a oeste (Botucatu) e esparsamente no Vale do Paraíba. No início dos anos 30, com a crise do café, o algodão representou uma busca de alternativas de lucros, e seu cultivo, aliado a indústria têxtil paulista, deu início aos complexos agroindustriais (ALBUQUERQUE 1982).

O cultivo de laranjeiras, que no início do povoamento do Estado, era somente doméstico, incorporou novas tecnologias, e hoje, o assim conhecido corredor citrícola, abrangendo as divisões regionais agrícolas de Campinas, Ribeirão Preto e São José do Rio Preto, é um dos mais importantes pólos agroindustriais do Estado (MARTINELLI 1987).

Na década de 50 e 60, a agroindústria canavieira foi retomada. Em 1975, com o Programa Nacional do Álcool (PROÁLCOOL), foram instaladas usinas para o 
processamento da cana. Com isso, o cultivo da cana se tornou novamente vantajoso. No período mais recente, as regiões de Ribeirão Preto, Barretos, Franca, São Carlos, São José do Rio Preto, Araçatuba e Presidente Prudente configuram os mais importantes pólos da agroindústria canavieira (RAMOS 1983).

Em 1996, a agricultura paulista concentrou-se em duas atividades econômicas: a cana-de-açúcar e a pecuária bovina. Devido à ampla base tecnológica das regiões de agroindústrias, houve uma diminuição de demanda para a mão de obra empregada, com a conseqüente mudança da oferta de trabalhadores especializados e assalariados. Formaram-se pólos de agricultura intensiva e moderna, com algumas regiões tentando se integrar a esse padrão, e regiões marginais que não conseguiram atingir este objetivo (CHABARIBERY 1999).

Deve-se também levar em consideração, que o meio rural paulista não pode ser apenas considerado como o conjunto das atividades agropecuárias e agroindustriais; pois novos tipos de ocupação foram sendo implementados, como o lazer, eco-turismo e moradia. Além disso, várias atividades tipicamente urbanas estão se tornando mais freqüentes no meio rural, ampliando a oferta de trabalho para ocupações como motorista de ônibus para transporte dos trabalhadores rurais, secretárias, trabalhadores domésticos, administradores, etc (SILVA et al. 1996). 


\section{JUSTIFICATIVA}

Os agravos à saúde bucal, assim como os agravos à saúde geral são determinados por fatores complexos, que envolvem desde políticas de desenvolvimento até o grau de organização dos serviços de saúde, fatores condicionantes das imensas desigualdades sociais no Brasil (WALDMAN et al. 2000).

Apesar de poucos estudos descreverem as condições socioeconômicas dos residentes em áreas rurais brasileiras, dados oficiais apontam piores indicadores de renda, escolaridade e de saneamento em áreas rurais do Estado de São Paulo, o rendimento médio mensal e a proporção de pessoas com 10 anos ou mais e com ao menos um ano de instrução na área urbana representam o dobro dos valores encontrados na área rural (SEADE 2003). Sabe-se que essas características podem ter reflexos desfavoráveis nos níveis de saúde bucal da população rural paulista (MELLO e ANTUNES 2004).

Apesar da acentuada expansão dos serviços de saúde na área odontológica (JUNQUEIRA 2001), o excesso de demanda por esses serviços, sua distribuição e acessibilidade não homogêneas configuram fatores que ampliam a desigualdade (BOTAZZO 1999). Os dados da Pesquisa Nacional por Amostras de Domicílios PNAD, realizada em 2003 (BRASIL 2005) são consistentes com essa afirmação quando demonstram que o acesso a consultas médicas e odontológicas aumenta 
expressivamente com a renda, sendo maior nas áreas urbanas. Ao indicar piores condições socioeconômicas e maior dificuldade de acesso a serviços de saúde, sugere-se que a população rural possa configurar um pólo de concentração para os agravos à saúde bucal. Entretanto, sabendo-se que as áreas rurais do Estado de São Paulo não são homogêneas, deve-se identificar quais são aquelas onde os escolares têm risco mais elevado de apresentar as doenças bucais. Apesar disso, poucos estudos foram realizados para caracterizar as condições de saúde bucal da população rural brasileira (MARQUES et al. 1986; FURTADO et al. 1999) e o restrito número de estudos disponíveis são, em sua maioria, descritivos de situações encontradas em uma única área.

Para promover a saúde bucal de modo efetivo, os responsáveis pelos serviços de saúde precisam conhecer a distribuição dos agravos e das necessidades de tratamento dentário preventivo e restaurador em cada segmento de nossa sociedade, para assim prever e planejar ações de saúde específicas e adequadas às suas necessidades. Essa observação salienta a importância da utilização da Epidemiologia para o planejamento de serviços odontológicos; de acordo com MORGENSTERN (1998), os estudos epidemiológicos são muito relevantes para observar o impacto de variáveis sociais na saúde das populações e para avaliar novos programas de saúde ou aqueles em andamento.

O presente estudo procura trazer informações epidemiológicas inéditas sobre os diferenciais entre os indicadores de saúde bucal de populações residentes em áreas urbanas e rurais do Estado de São Paulo, fornecendo subsídios para o planejamento de ações preventivas e assistenciais do sistema de saúde. 


\section{OBJETIVOS}

\subsection{Objetivo geral}

Estudar os diferenciais entre os indicadores de cárie dentária e alterações gengivais em escolares de áreas urbanas e rurais do Estado de São Paulo.

\subsection{Objetivos específicos:}

1. Estimar indicadores epidemiológicos de prevalência de cárie dentária (CPO-D, ceo-d e Índice de Cuidado) e de alterações gengivais (Índice Periodontal Comunitário, $\mathrm{CPI}^{*}$ ) de escolares de áreas rurais do Estado de São Paulo.

2. Comparar os indicadores de saúde bucal de áreas urbanas e rurais, assim como identificar fatores associados aos mesmos.

3. Elaborar hipóteses explicativas de possíveis diferenciais entre os indicadores da prevalência de cárie e de alterações gengivais em áreas rurais com fundamento no padrão de distribuição espacial e em características do desenvolvimento rural em diferentes regiões do Estado.

\footnotetext{
* CPI abreviação amplamente utilizada de Community Periodontal Index
} 


\section{MATERIAL E MÉTODOS}

\subsection{Desenho do Estudo}

O presente trabalho utiliza-se de dois desenhos de estudos epidemiológicos. Primeiramente realizou-se um estudo transversal de cunho analítico. Trata-se de um estudo epidemiológico onde a unidade de estudo é o indivíduo e cujo objetivo é descrever as condições de saúde de uma dada população em determinada área e tempo testando associações de interesse (PERES e ANTUNES 2006).

Em seguida, as unidades de estudo foram os agregados populacionais, tratando-se de estudo ecológico, possibilitando o teste de associações entre prevalência de cárie e condições gengivais com variáveis socioeconômicas dos municípios e de diferentes áreas rurais (MORGENSTERN 1998).

\subsection{Caracterização da área de estudo.}

O Estado de São Paulo, localizado na Região Sudeste do Brasil, possui um território de 248.209,426 $\mathrm{Km}^{2}$, com população estimada para o ano $2000 \mathrm{em}$ 37.032.403 habitantes, dos quais $2.439 .552(6,59 \%)$ encontra-se em áreas rurais (IBGE 2000). O Estado possui indicadores sócio-demográficos e padrões de morbimortalidade muito heterogêneos, o coeficiente de mortalidade infantil variava em 1998 de 14 por mil nascidos vivos, em municípios mais ricos (por exemplo, Botucatu) até cerca de 40 por mil nos municípios mais pobres (por exemplo, Itapeva) 
(SEADE 2005). Assim como vem ocorrendo em diversos países do mundo, as diferentes regiões do Estado possuem padrões epidemiológicos bastante heterogêneos. Indicadores de escolaridade revelam que enquanto $7 \%$ dos residentes na área urbana do Estado não tiveram nem um ano de estudo, na área rural esse número eleva-se para 13\% (IBGE 2000).

A área rural do Estado de São Paulo também é bastante heterogênea, apresentando extremos de áreas muito pobres de agricultura pouco desenvolvida e pólos muito ricos de agroindústria. As sete principais mesoregiões rurais do Estado, por ordem de importância são: São José do Rio Preto, Ribeirão Preto, Campinas, Bauru, Presidente Prudente, Itapetininga e Macro metropolitano Paulista, foram responsáveis, em 1995, por aproximadamente $70 \%$ do total dos itens selecionados para a agropecuária paulista. Neste mesmo ano, as atividades econômicas com maior participação de mão de obra empregada foram a pecuária $(31,1 \%)$ e as lavouras temporárias $(30,8 \%)$ das quais se destaca como principal empregadora a da cana-deaçúcar. As lavouras permanentes foram responsáveis pela ocupação de 20,3\% do pessoal sendo a do café e da laranja as principais (SEADE 2003).

\subsection{População de estudo}

Estudantes de escolas urbanas e rurais do Estado de São Paulo de 5 a 7 e 10 a 12 anos, participantes do Levantamento Epidemiológico de Saúde Bucal promovido pela Secretaria de Estado da Saúde de São Paulo e Faculdade de Saúde Pública da Universidade de São Paulo, em 1998 (USP, 1999). 


\subsection{Definição de caso}

\subsubsection{Cárie dentária}

Estudantes de ambos os sexos, pertencentes às faixas etárias de 5 a 7 e 10 a 12 anos que freqüentavam escolas urbanas e rurais do Estado de SP, apresentando na coroa dentária, cavidade evidente de cárie ou experiência prévia semelhante com o dente restaurado ou extraído, durante o exame realizado pelo Levantamento de Saúde Bucal, entre os meses de agosto a dezembro de 1998.

\subsubsection{Alterações gengivais}

Estudantes de ambos os sexos, pertencentes às faixas etárias de 5 a 7 e 10 a 12 anos que freqüentavam escolas urbanas e rurais do Estado de SP, apresentando sangramento após a sondagem do sulco gengival ou cálculo em pelo menos um sextante, durante o exame realizado pelo Levantamento de Saúde Bucal, entre os meses de agosto a dezembro de 1998.

\subsection{Amostra}

A amostra original do Levantamento de saúde bucal (USP 1999) foi calculada de acordo com as recomendações da Organização Mundial da Saúde (WHO 1997). A OMS considera que amostras contendo 40 crianças por idade são suficientes para a obtenção de dados confiáveis. Este número está relacionado às características específicas da distribuição da cárie em populações quando se sabe, através de amostra-piloto ou levantamento anterior, que a prevalência do agravo à saúde bucal 
estudado é "moderada" ou "alta" na população de referência. O Levantamento Epidemiológico de Saúde Bucal (USP, 1999) optou por admitir um "erro de desenho" $=2$, a esse número (80), acrescentou-se mais 16 elementos amostrais correspondentes a uma perda estimada em 20\%. Assim, fixou-se em 96 o número de elementos amostrais por estrato. Adotou-se uma técnica de amostragem por conglomerado.

A coleta dos dados primários ocorreu no período de agosto a dezembro de 1998. No total, 89.114 pessoas foram examinadas, das quais 73.246 de 5 a 12 anos, 5.195 escolares de 18 anos, 5.778 na faixa etária de 35 a 44 anos e 4.895 de 65 a 74 anos. Os resultados obtidos permitem inferência, na faixa etária de 5 a 12 anos, para o Estado de São Paulo, cada uma das 24 Direções Regionais de Saúde (DIRs) e para cada um dos municípios sorteados para integrar a amostra. Apesar de não estar contemplada a perspectiva de representatividade nos estratos, a caracterização das crianças examinadas permite, para fins exploratórios, a estratificação da amostra segundo sexo, grupo étnico, tipo de escola (pública ou particular), localidade da escola (urbana ou rural), Direção Regional de Saúde, disponibilidade de água fluoretada no núcleo urbano do município, porte do município (pequeno, médio, grande, classificados segundo o número de habitantes). O relatório final do estudo original permite aprofundamentos da metodologia aplicada e resultados obtidos (USP 1999).

Todas as crianças das duas faixas etárias: 5 a 7 (para o estudo da dentição decídua) e 10 a 12 anos (para o estudo da dentição permanente) selecionadas e que efetivamente participaram do Levantamento Epidemiológico de Saúde Bucal (USP, 1999) foram incluídas neste estudo, totalizando 53.037 escolares. 


\section{6 Fontes de dados}

\subsubsection{Levantamento epidemiológico de saúde bucal (USP 1999).}

Os dados utilizados neste estudo foram obtidos do Levantamento Epidemiológico de Saúde Bucal realizado por meio de um Convênio de Cooperação Técnica entre a Secretaria de Estado de Saúde (SES) e a Faculdade de Saúde Pública da Universidade de São Paulo (FSP-USP) de outubro de 1997 a outubro de 1999, incluindo as etapas de planejamento e de apuração e análise dos dados, sendo o mais abrangente levantamento de saúde bucal do Estado de São Paulo.

O objetivo do levantamento foi obter dados que permitissem avaliar as condições de saúde bucal da população de 5 a 12 e de 18 anos de idade do Estado de São Paulo, em 1998. Adicionalmente, também foi estabelecido como objetivo da pesquisa obter dados exploratórios para adultos de 35 a 44 anos vinculados às unidades de ensino pública e privada do Estado e idosos de 65 a 74 anos de idade.

Participaram do levantamento 133 municípios do Estado e aproximadamente 800 profissionais foram envolvidos entre examinadores, anotadores e coordenadores. Os exames bucais foram realizados de acordo com as orientações do Manual da Organização Mundial da Saúde (WHO 1997) e com o objetivo de garantir adequada precisão dos resultados de uma pesquisa multicêntrica, a estratégia empregada foi a realização de treinamentos e calibrações regionais com os 303 examinadores em todas as 24 regiões de saúde do Estado de São Paulo. De acordo com FRIAS (2000), levando-se em conta a complexidade da pesquisa e observando-se os resultados dos indicadores de confiabilidade, pode-se afirmar que os objetivos propstos na calibração dos examinadores foram atingidos. A OMS (1997) considera 
a discordância em torno de 10 a 15\% aceitável. Foram obtidos dados relativos aos seguintes problemas de saúde bucal: cárie dentária, doença periodontal, oclusão dentária, fluorose dentária e uso de prótese dentária. Também foram dimensionadas as necessidades de tratamento odontológico e de prótese dentária.

Além das características dos escolares participantes, como sexo, grupo étnico, localização (urbana e rural) e tipo de escola (pública e privada), também foram utilizados os dados do Levantamento Epidemiológico de Saúde Bucal (USP 1999) para obter informações de características sócio-demográficas dos municípios participantes, como a presença ou não de flúor na água de abastecimento público.

\subsubsection{Dados socioeconômicos municipais}

Características socioeconômicas de cada município participante na amostra foram obtidas através do Índice de Desenvolvimento Humano Municipal (IDH-M), disponibilizado pelo Escritório Regional no Brasil do Programa das Nações Unidas para o Desenvolvimento (PNUD). Esse índice mede o nível de desenvolvimento humano municipal através de indicadores de educação (taxa de alfabetização de pessoas acima de 15 anos de idade e taxa bruta de freqüência à escola), longevidade (expectativa de vida ao nascer) e renda (renda municipal per capita).

\subsection{Variáveis de estudo}

Os indicadores de prevalência de cárie não tratada $(\mathrm{C} \geq 1$, para dentes permanentes, ou $\mathrm{c} \geq 1$, para dentes decíduos) e os indicadores de prevalência de 
alterações gengivais: sangramento gengival à sondagem $(\mathrm{CPI} \geq 1)$ e presença de cálculo dentário $(\mathrm{CPI}=2)$ foram utilizados como variáveis dependentes.

As variáveis independentes que foram analisadas são:

a) Variáveis utilizadas para estimar a associação no nível das crianças examinadas: gênero, grupo étnico, localização e tipo de escola. A classificação de grupo étnico é estudada em duas categorias: "negros" (isto é, crianças de descendência africana, incluindo as que foram classificadas como "pardas"), e "não negros" (isto é, crianças brancas de descendência européia). A amostra ainda continha um pequeno número de crianças "amarelas", isto é, de descendência asiática, que para fins do presente estudo foram consideradas "não-negras". Não havia nenhum outro grupo étnico caracterizado no levantamento. Localização diz respeito à classificação das escolas nas áreas urbana e rural das cidades participantes do levantamento. Tipo de escola refere-se à diferenciação entre pública e privada. Como as escolas públicas são gratuitas, estudos de epidemiologia da saúde bucal têm presumido que crianças matriculadas em estabelecimentos privados de ensino no contexto brasileiro apresentam melhores condições socioeconômicas que as crianças de escolas públicas (PERES et al. 1997; TRAEBERT et al. 2001).

b) Variáveis utilizadas para avaliar a associação no nível das cidades participantes do levantamento: informações sobre as condições socioeconômicas dos municípios (IDH-M, índice que mede o desenvolvimento humano a partir de indicadores de educação, longevidade e renda) e a presença de flúor na rede de abastecimento de água (USP 1999). 


\subsection{Análise}

As variáveis do estudo foram organizadas na forma de banco de dados informatizado e a análise estatística foi efetuada através dos programas Epi Info 6.04d 2001 e SPSS 8.0 1997.

\subsubsection{Cálculo dos indicadores de saúde bucal}

\subsubsection{Indicador de cárie dentária}

O levantamento utilizou os índices ceo-d e CPO-D para avaliar a prevalência e a gravidade do ataque de cárie. Esses índices contabilizam, respectivamente, os dentes decíduos e permanentes de algum modo afetados por cárie (cariados, extraídos ou restaurados) (WHO 1997). Com base nessas informações, foi possível estimar a prevalência de necessidades de tratamento odontológico. A variável é definida pela manifestação de ao menos um dente, decíduo ou permanente, com cárie não tratada (isto é, o componente "c" do índice ceo-d, ou o componente "C" do índice CPO-D, maior ou igual a 1) para avaliações no nível individual; e pela proporção de crianças apresentando esta condição em cada área, para avaliações no nível agregado. Assim definida, essa variável congrega informação sobre a prevalência de cárie e a falta de acesso a tratamento odontológico; e é especialmente interessante para avaliações em crianças de cinco a sete anos, em função de uma relativamente baixa incorporação de tratamentos de restauração na dentição decídua (PERES et al. 2003). Esta medida foi amplamente usada para a comparação de sistemas de saúde bucal, em um estudo colaborativo internacional realizado por 
pesquisadores da Organização Mundial da Saúde e da Universidade de Chicago (CHEN et al. 1997).

O Índice de Cuidado (IC) também foi estimado. Esse indicador foi originalmente proposto por Walsh (1970) para estudos comparativos de avaliação de programas de atendimento odontológico, e pode ser facilmente calculado pelo quociente entre o número de dentes decíduos e permanentes obturados pelos respectivos valores globais de ceo-d e CPO-D, para cada faixa etária. Utiliza como escala a porcentagem e corresponde a proporção de dentes já tratados dentre o conjunto de dentes com história de ataque de cárie. Sendo um indicador de dados agregados é utilizado no segundo nível da análise de regressão, dos municípios, e na análise por áreas rurais homogêneas.

\subsubsection{Indicador de alterações gengivais}

Para a análise das alterações gengivais os dados do Levantamento (USP 1999) permitem calcular o Índice Periodontal Comunitário (CPI*) (WHO 1997). Os arcos dentais são divididos em sextantes e dentes índices são examinados. Em indivíduos menores de 15 anos o Índice Periodontal Comunitário (CPI) classifica cada sextante da boca como saudável $(\mathrm{CPI}=0)$; presença de sangramento após a sondagem $(\mathrm{CPI}=1)$; ou presença de cálculo detectável durante a sondagem $(\mathrm{CPI}=2)$. Permite identificar os problemas gengivais mesmo iniciais em idades precoces.

\footnotetext{
* CPI abreviação amplamente utilizada de Community Periodontal Index
} 


\subsubsection{Descrição da distribuição dos agravos nas áreas urbana e rural}

$\mathrm{Na}$ primeira etapa, foram obtidos os indicadores globais de saúde bucal do Estado de São Paulo, segundo a estratificação urbana / rural. Após o cálculo dos índices apresentados anteriormente, os diferenciais entre esses dois segmentos foram estimados através da razão desses indicadores, ou seja, o indicador de prevalência do grupo 1 (rural) em relação ao grupo 2 (urbano), através da qual obteve-se um indicador do diferencial entre essas áreas. Deram origem a essas razões as variáveis: média de dentes cariados ("c" na dentição decídua e "C" na dentição permanente), média de dentes perdidos ("e" na dentição decídua e "P" na dentição permanente), média de dentes obturados (“o” na dentição decídua e "O” na dentição permanente), índice de cárie (ceo-d e CPO-D, respectivamente para a dentição decídua e permanente), porcentagem de crianças livres de cárie (ceo- $d=0$ e CPO-D=0) e índice de cuidado (IC). Nesse sentido, razões mais elevadas que 1 (um) indicam valores mais elevados para a zona rural e vice-versa. Do mesmo modo, valores não significantemente diferentes da unidade para essas razões indicam valores equivalentes para os dois grupos de população estudados.

Os indicadores de cárie não tratada $(\mathrm{C} \geq 1$, para dentes permanentes, ou $\mathrm{c} \geq 1$, para dentes decíduos) e os indicadores de alterações gengivais: sangramento gengival à sondagem $(\mathrm{CPI} \geq 1)$ e presença de cálculo dentário $(\mathrm{CPI}=2)$ foram utilizados como variáveis dependentes para cada estrato (urbano e rural) e as razões de chances (OR) foram calculadas de acordo com as características sócio-demográficas das crianças e, num primeiro momento, de modo não ajustado para as demais variáveis do estudo. 


\subsubsection{Análise multinível}

Empregou-se a análise multinível para o posterior ajuste de determinantes individuais e contextuais que podem interferir nos agravos à saúde bucal estudados, cárie dentária e condições gengivais, com controle de colinearidade para as variáveis independentes em cada nível da análise. A avaliação da qualidade do ajuste do modelo empregou o teste -2loglikelihood. A análise multinível utilizou o esquema de efeitos fixos/intersecção randômica (SNIJDERS e BOSKER 2003), para ajustar os indicadores de saúde bucal estudados com variáveis independentes relativas às crianças examinadas (primeiro nível) e às cidades participantes (segundo nível). O teste "likelihood-ratio test" foi utilizado para decidir se o modelo completo era significativamente mais bem ajustado que o modelo contendo apenas o primeiro nível (JOHNSON 1998).

No primeiro nível, uma análise multivariada de regressão logística convencional, compreendendo todas as crianças examinadas, permitiu avaliar o efeito das características sociodemográficas sobre a condição considerada. No segundo nível, uma análise multivariada de regressão logística convencional foi executada para cada cidade. Estas equações tiveram seus coeficientes fixados para coincidir com os previamente determinados pela equação, compreendendo o banco de dados completo, pois este modelo não admite variação de segundo nível nos efeitos das variáveis independentes de primeiro nível. Desse modo, toda a variação de segundo nível foi atribuída à intersecção, e uma análise de regressão linear avaliou a variação da intersecção.

Uma indicação esquemática desse procedimento analítico foi descrita no trabalho de ANTUNES et al. (2006a). 


\subsubsection{Análise espacial segundo características do desenvolvimento rural}

Para elaborar hipóteses explicativas de possíveis diferenciais da prevalência de cárie e de condições gengivais em áreas rurais com fundamento no padrão de distribuição espacial e em características do desenvolvimento rural em diferentes regiões do Estado, utilizou-se a Classificação de CHABARIBERY (1999) que identificou 12 classes no Estado mediante a análise das seguintes características da área rural: intensidade de exploração da terra; conservação e uso dos recursos naturais; grau de mecanização e capacidade produtiva da força de trabalho; modernização das relações de trabalho; grau de integração das instituições; grau de urbanização do município; condições de vida e bem-estar social. As características de cada uma dessas classes são as seguinte:

Classe 1: Caracteriza-se por agricultura familiar sem absorção de mão de obra externa, pouco modernizada, baixo rendimento, baixos indicadores de renda média (10,4\% dos chefes de domicílio rural recebendo renda mensal de menos de um salário mínimo).

Classe 2: Agricultura familiar pouco modernizada e de baixo rendimento, em regiões com economia deprimida e com poucas oportunidades de geração de renda.

Classe 3: Agricultura familiar e patronal de médios a grandes estabelecimentos com baixa eficiência na produção, apesar da utilização de alguns insumos modernos, em regiões de baixa densidade demográfica, pequeno crescimento populacional e baixo nível de condição de vida, indicando economia deprimida.

Classe 4: Classe de agricultura patronal e familiar em grandes estabelecimentos de média produtividade, em regiões relativamente urbanizadas, e baixo índice de condições de vida. 
Classe 5: Agricultura patronal e familiar, que apresenta baixa modernização em médios a grandes estabelecimentos de média produtividade, em regiões com pouco dinamismo na economia local, mas com presença de centros urbanos de maior atividade.

Classe 6: Classe com significativa participação de força de trabalho externa, porém ainda patronal e familiar com produção agropecuária de pouco valor e áreas com restrições naturais, em regiões com entorno socioeconômico que apresenta dinamismo em nível médio.

Classe 7: Agricultura familiar de baixa renda, em regiões de condições naturais restritas e muito baixas condições de vida, abrangendo regiões deprimidas e de baixa dinâmica econômica.

Classe 8: Exploração familiar e patronal em minifúndios com ocupação de mão-deobra externa, altos valores da produção e das despesas para produzir hortifrutigranjeiros absorvidos na própria dinâmica do entorno socioeconômico regional, densamente povoado e com elevada taxa de crescimento populacional.

Classe 9: Agricultura patronal e familiar em pequenos estabelecimentos com modernização agrícola e alto valor da produção, em regiões com dinamismo econômico e capacidade de geração de emprego e renda.

Classe 10: Agricultura patronal e familiar em propriedades de grande tamanho, que demonstra integração elevada à instituição financeira, com uso intensivo de terra e alta modernização agrícola, mas baixo grau de capacidade produtiva da força de trabalho. Mostra o mais alto índice de condições de vida dentre as classes, podendose afirmar que apresenta elevado dinamismo na atividade econômica. 
Classe 11: Agricultura altamente modernizada, realizada por grandes propriedades patronal e familiar, mas de alta produtividade por estabelecimento em um conjunto de municípios com relativo dinamismo econômico.

Classe 12: Agricultura familiar e patronal em estabelecimentos de tamanho médio a grande, com média produtividade, altamente modernizada, mas sem elevada integração com instituições de crédito. O entorno socioeconômico dos municípios que a compõem revela dinâmica populacional e econômica e alto índice de condições de vida.

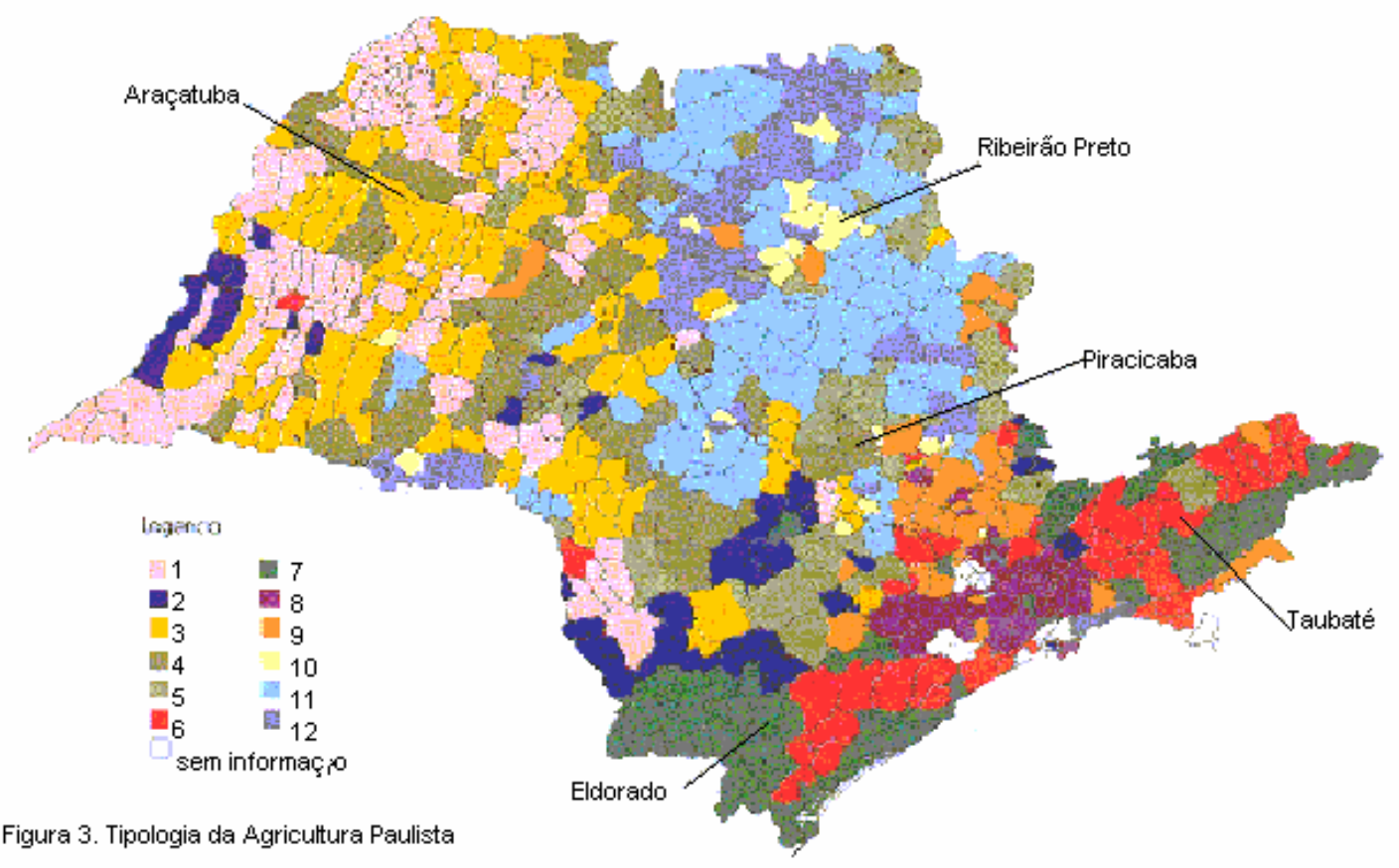

Fonte: Coleç. estud. agríc., São Paulo, n.7, p. 1-178, 1999.

Figura 5.8.4.1 Tipologia da agricultura paulista, 1995. 


\subsection{Aspectos éticos}

A pesquisa analisou bancos de dados secundários, observando as recomendações da Resolução no 196, de 10 de outubro de 1996, Conselho Nacional de Saúde para a Pesquisa Científica em Seres Humanos, sem a identificação nominal dos participantes de forma a garantir a privacidade das informações e o anonimato dos sujeitos da pesquisa, utilizando-se os dados assim obtidos exclusivamente para os propósitos desta pesquisa. O protocolo de pesquisa foi aprovado pela Comissão de Ética em Pesquisa da Faculdade de Saúde Pública da Universidade de São Paulo, parecer número 1096 (Anexo 1). 


\section{RESULTADOS}

\subsection{Descrição da população estudada}

Para o cálculo dos indicadores de saúde bucal na dentição decídua, fizeram parte deste estudo 22.733 crianças de áreas urbanas e 2.011 de áreas rurais do estado de São Paulo, totalizando 24.744 crianças examinadas. Diferenças estatisticamente significativas foram observadas quanto à distribuição etária das crianças com dentição decídua em áreas urbanas e rurais. Participaram do levantamento na área rural porcentagem mais elevada $(53,26 \%)$ de crianças de 7 anos e uma menor porcentagem $(18,30 \%)$ de crianças de 5 anos em relação a porcentagem de crianças das mesmas idades na área urbana $(\mathrm{p}, 0,001)$ (Tabela 6.1.1).

Tabela 6.1.1 Distribuição das crianças examinadas para os indicadores de saúde bucal na dentição decídua, segundo a idade, em áreas urbanas e rurais, estado de São Paulo, 1998.

\begin{tabular}{cccccccc}
\hline \multirow{2}{*}{ Idade } & \multicolumn{2}{c}{ Urbano } & \multicolumn{2}{c}{ Rural } & \multicolumn{2}{c}{ Total } & \\
\cline { 2 - 6 } & $\mathbf{N}$ & $\mathbf{\%}$ & $\mathbf{N}$ & $\mathbf{\%}$ & $\mathbf{N}$ & $\mathbf{\%}$ & \\
\hline $\mathbf{5}$ anos & 6146 & 27,0 & 368 & 18,3 & 6514 & 26,3 & $<0,001$ \\
$\mathbf{6}$ anos & 8167 & 35,9 & 572 & 28,4 & 8739 & 35,3 & $<0,001$ \\
7 anos & 8420 & 37,0 & 1071 & 53,3 & 9491 & 38,4 & $<0,001$ \\
\hline Total & 22733 & 100,0 & 2011 & 100,0 & 24744 & 100,0 & - \\
\hline
\end{tabular}


$\mathrm{Na}$ dentição permanente, para o cálculo dos indicadores de saúde bucal fizeram parte deste estudo 25.916 escolares de áreas urbanas e 2.377 de áreas rurais do estado de São Paulo, totalizando 28.293 escolares examinados. Comparando os escolares de área urbana com os de área rural verificamos diferenças na distribuição etária com predomínio dos mais novos entre os da área rural $(\mathrm{p}<0,001)$, conforme Tabela 6.1.2.

Tabela 6.1.2 Distribuição das crianças examinadas para os indicadores de saúde bucal na dentição permanente, segundo a idade, em áreas urbanas e rurais, Estado de São Paulo, 1998.

\begin{tabular}{cccccccc}
\hline \multirow{2}{*}{ Idade } & \multicolumn{2}{c}{ Urbana } & \multicolumn{2}{c}{ Rural } & \multicolumn{2}{c}{ Total } & \\
\cline { 2 - 7 } & $\mathbf{N}$ & $\mathbf{\%}$ & $\mathbf{N}$ & $\mathbf{\%}$ & $\mathbf{N}$ & $\mathbf{\%}$ & \\
\hline $\mathbf{1 0}$ anos & 8783 & 33,9 & 1052 & 44,3 & 9835 & 34,8 & $<0,001$ \\
$\mathbf{1 1}$ anos & 8519 & 32,9 & 740 & 31,1 & 9259 & 32,7 & 0,084 \\
$\mathbf{1 2}$ anos & 8614 & 33,2 & 585 & 24,6 & 9199 & 32,5 & $<0,001$ \\
\hline Total & 25916 & 100,0 & 2377 & 100,0 & 28293 & 100,0 & - \\
\hline
\end{tabular}

A Tabela 6.1.3 descreve as crianças de 5 a 7 anos de acordo com características sócio-demográficas disponíveis nos dados do levantamento. Não foi encontrada diferença estatisticamente significativa entre a distribuição por gêneros nas áreas urbana e rural $(\mathrm{p}>0,05)$. Entretanto, nas áreas rurais participaram do levantamento uma maior porcentagem de crianças negras e pardas $(55,4 \%)(p<0,001)$ e uma porcentagem muito pequena de crianças matriculadas em escolas privadas $(1,9 \%)(p<0,001)$ em contraste ao observado para as áreas urbanas do estado. 
Tabela 6.1.3. Distribuição de escolares de 5 a 7 anos de áreas urbanas e rurais, segundo as características sócio-demográficas, estado de São Paulo, 1998.

\begin{tabular}{rcccccc}
\hline \multirow{2}{*}{ Características } & \multicolumn{2}{c}{ Urbana } & \multicolumn{2}{c}{ Rural } & \multirow{2}{*}{ Valor de p } \\
\cline { 3 - 5 } & $\mathbf{N}$ & $\mathbf{\%}$ & $\mathbf{N}$ & $\mathbf{\%}$ & \\
\hline Sexo & & & & & \\
& Feminino & 11189 & 49,2 & 980 & 48,7 & 0,675 \\
Masculino & 11544 & 50,8 & 1031 & 51,3 & 0,675 \\
Grupo étnico & & & & & \\
Não negros & 12241 & 53,8 & 897 & 44,6 & $<0,001$ \\
Negros e pardos & 10492 & 46,1 & 1114 & 55,4 & $<0,001$ \\
Tipo de escola & & & & & \\
Privada & 1499 & 6,6 & 38 & 1,9 & $<0,001$ \\
Pública & 21234 & 93,4 & 1973 & 98,1 & $<0,001$ \\
\hline
\end{tabular}

A Tabela 6.1.4 descreve as crianças de 10 a 12 anos de acordo com características sócio-demográficas disponíveis nos dados do levantamento. Não foi encontrada diferença estatisticamente significativa entre a distribuição por gêneros nas áreas urbana e rural. Entretanto, nas áreas rurais participaram do levantamento uma maior porcentagem de crianças negras e pardas $(59,8 \%)(p<0,001)$ e uma porcentagem muito pequena de crianças matriculadas em escolas privadas $(2,6 \%)$ $(\mathrm{p}<0,001)$ em contraste ao observado para as áreas urbanas do estado.

Tabela 6.1.4. Distribuição de escolares de 10 a 12 anos de áreas urbanas e rurais, segundo as características sócio-demográficas, Estado de São Paulo, 1998.

\begin{tabular}{rccccc}
\hline \multirow{2}{*}{ Características } & \multicolumn{2}{c}{ Urbana } & \multicolumn{2}{c}{ Rural } & Valor de p \\
\cline { 2 - 5 } & $\mathbf{N}$ & $\mathbf{\%}$ & $\mathbf{N}$ & $\mathbf{\%}$ & \\
\hline Sexo & & & & & \\
Feminino & 13433 & 51,8 & 1225 & 51,5 & 0,799 \\
$\quad \begin{array}{l}\text { Masculino } \\
\text { Grupo étnico }\end{array}$ & 12483 & 48,2 & 1152 & 48,5 & 0,784 \\
$\quad$ Não negros & 12859 & 49,6 & 956 & 40,2 & $<0,001$ \\
$\begin{array}{c}\text { Negros e pardos } \\
\text { Tipo de escola }\end{array}$ & 13057 & 50,4 & 1421 & 59,8 & $<0,001$ \\
$\begin{array}{r}\text { Privada } \\
\text { Pública }\end{array}$ & 1368 & 5,3 & 62 & 2,6 & $<0,001$ \\
& 24546 & 94,7 & 2316 & 97,4 & $<0,001$ \\
\hline
\end{tabular}




\subsection{Cárie dentária}

As crianças de áreas rurais do estado de São Paulo apresentaram piores indicadores de experiência de cárie e acesso a tratamento odontológico na dentição decídua que àquelas de áreas urbanas $(\mathrm{p}<0,001)$. Na área rural, apenas $19,5 \%$ das crianças estavam livres de cárie e somente $21,2 \%$ tiveram acesso a tratamento odontológico, tais proporções quando comparadas com a das crianças de áreas urbanas mostraram diferenças estatisticamente significativas $(p<0,01)$ (Tabela 6.2.1).

Tabela 6.2.1 Experiência de cárie dentária na dentição decídua, acesso a tratamento odontológico e número de crianças examinadas de 5 a 7 anos, em áreas urbanas e rurais, São Paulo, 1998.

\begin{tabular}{ccccc}
\hline Índices & Urbana & Rural & Razão R/U & p \\
\hline Dentes cariados & 2,14 & 3,49 & 1,63 & $<0,01$ \\
Dentes perdidos & 0,12 & 0,17 & 1,42 & $<0,01$ \\
Dentes obturados & 1,11 & 0,98 & 0,88 & 0,05 \\
ceo-d & 3,37 & 4,64 & 1,38 & $<0,01$ \\
Livres de cárie (ceo-d=0) & $30,92 \%$ & $19,55 \%$ & 0,63 & $<0,01$ \\
Índice de cuidado (IC) & $32,89 \%$ & $21,20 \%$ & 0,64 & $<0,01$ \\
Número de crianças examinadas & 22975 & 2036 & & \\
\hline
\end{tabular}

ceo-d = dentes decíduos cariados, perdidos e obturados

Na dentição permanente, também se observou maior prevalência de cárie e necessidade de tratamento para os escolares de áreas rurais do estado. A análise dos componentes do índice CPO-D demonstra que a média de dentes cariados e perdidos é maior em áreas rurais enquanto a proporção de dentes cariados que já foram restaurados (IC) é maior em áreas urbanas se comparadas às de área rural $(\mathrm{p}>0,001)$. Apenas $47,5 \%$ das necessidades de tratamento odontológico nas áreas rurais foram 
atendidas e somente $20 \%$ dos escolares da mesma área estão livres de cárie, proporções inferiores àquelas encontradas em áreas urbanas $(p>0,001)$ (Tabela $6.2 .2)$.

Tabela 6.2.2 Experiência de cárie dentária na dentição permanente, acesso a tratamento odontológico e número de crianças examinadas em áreas urbanas e rurais, São Paulo, 1998.

\begin{tabular}{ccccc}
\hline Índices & Urbana & Rural & Razão R/U & p \\
\hline Dentes cariados & 1,00 & 1,57 & 1,57 & $<0,001$ \\
Dentes perdidos & 0,07 & 0,14 & 2,00 & $<0,001$ \\
Dentes obturados & 1,81 & 1,54 & 0,85 & $<0,001$ \\
CPO-D & 2,88 & 3,25 & 1,13 & $<0,001$ \\
Livres de cárie (CPO-D=0) & $26,17 \%$ & $20,03 \%$ & 0,77 & $<0,001$ \\
Índice de cuidado (IC) & $62,91 \%$ & $47,55 \%$ & 0,76 & $<0,001$ \\
Número de crianças examinadas & 26298 & 2417 & & \\
\hline
\end{tabular}

CPO-D $=$ dentes permanentes cariados, perdidos e obturados

Foram analisadas as condições sócio-demográficas que poderiam estar associadas à necessidade de tratamento odontológico na dentição decídua. Na faixa etária de 5 a 7 anos, apresentaram maior prevalência de cárie não tratada crianças negras e pardas (em relação às brancas) e crianças matriculadas em escolas públicas (em relação às matriculadas em escolas privadas) tanto em áreas urbanas como rurais. Pertencer ao sexo feminino mostrou-se associado menor prevalência de cavidade de cárie não tratada nas duas áreas estudadas, Odds Ratio (OR) bruto de 0,83, sendo que o intervalo de confiança $\left(\mathrm{IC}_{95 \%}\right)$ apresentou-se limítrofe para os de área rural. 
Tabela 6.2.3. Distribuição de escolares de 5 a 7 anos de áreas urbanas e rurais, segundo a prevalência de cárie não tratada $(\mathrm{c} \geq 1)$ e características sócio-demográficas, Estado de São Paulo, Brasil, 1998.

\begin{tabular}{|c|c|c|c|c|c|c|}
\hline \multirow[b]{2}{*}{ Condição } & \multicolumn{3}{|c|}{$\begin{array}{c}\text { Urbana } \\
(\mathrm{n}=\mathbf{2 2 . 7 3 3 )}\end{array}$} & \multicolumn{3}{|c|}{$\begin{array}{c}\text { Rural } \\
(\mathrm{n}=\mathbf{2 . 0 1 1})\end{array}$} \\
\hline & $c \geq 1$ & $\mathbf{c}=\mathbf{0}$ & $\begin{array}{c}\text { OR bruto } \\
\text { (IC 95\%) }\end{array}$ & $c \geq 1$ & $\mathbf{c}=\mathbf{0}$ & $\begin{array}{c}\text { OR bruto } \\
\text { (IC 95\%) }\end{array}$ \\
\hline $\begin{array}{l}\text { Sexo } \\
\text { masculino } \\
\text { feminino }\end{array}$ & $\begin{array}{l}6804 \\
6081\end{array}$ & $\begin{array}{l}4740 \\
5108\end{array}$ & $\begin{array}{c}1,00 \\
0,83(0,79 ; 0,87) \\
p<0,001\end{array}$ & $\begin{array}{l}776 \\
703\end{array}$ & $\begin{array}{l}255 \\
277\end{array}$ & $\begin{array}{c}1,00 \\
0,83(0,68 ; 1,02) \\
\mathrm{p}=0,073\end{array}$ \\
\hline $\begin{array}{l}\text { Grupo étnico } \\
\text { não negros } \\
\text { negros e pardos }\end{array}$ & $\begin{array}{l}6515 \\
6370\end{array}$ & $\begin{array}{l}5726 \\
4122\end{array}$ & $\begin{array}{c}1,00 \\
1,36(1,29 ; 1,43) \\
p<0,001\end{array}$ & $\begin{array}{l}634 \\
845\end{array}$ & $\begin{array}{l}263 \\
269\end{array}$ & $\begin{array}{c}1,00 \\
1,30(1,06 ; 1,60) \\
p=0,009\end{array}$ \\
\hline $\begin{array}{l}\text { Tipo de escola } \\
\text { privada } \\
\text { pública }\end{array}$ & $\begin{array}{c}421 \\
12464\end{array}$ & $\begin{array}{l}1078 \\
8770\end{array}$ & $\begin{array}{c}1,00 \\
3,64(3,24 ; 4,09) \\
p<0,001\end{array}$ & $\begin{array}{c}19 \\
1479\end{array}$ & $\begin{array}{c}19 \\
513\end{array}$ & $\begin{array}{c}1,00 \\
2,88(1,45 ; 5,74) \\
p<0,001\end{array}$ \\
\hline
\end{tabular}

As mesmas variáveis sócio-demográficas foram testadas para a prevalência de cárie não tratada em dentes permanentes. Pertencer ao sexo masculino, ser negro ou pardo e freqüentar escola pública mostraram-se associados à prevalência de cavidade de cárie não tratada entre os escolares de áreas urbanas e rurais do estado, sendo que na zona rural as duas últimas associações não foram estatisticamente significativas (Tabela 6.2.4). 
Tabela 6.2.4. Distribuição de escolares de 10 a 12 anos de áreas urbanas e rurais, segundo a prevalência de cárie não tratada $(\mathrm{C} \geq 1)$ e características sócio-demográficas, Estado de São Paulo, Brasil, 1998.

\begin{tabular}{|c|c|c|c|c|c|c|}
\hline \multirow[b]{2}{*}{ Condição } & \multicolumn{3}{|c|}{$\begin{array}{c}\text { Urbana } \\
(n=25.916)\end{array}$} & \multicolumn{3}{|c|}{$\begin{array}{c}\text { Rural } \\
(n=2.377)\end{array}$} \\
\hline & $C \geq 1$ & $\mathrm{C}=\mathbf{0}$ & $\begin{array}{l}\text { OR bruto } \\
\text { (IC 95\%) }\end{array}$ & $C \geq 1$ & $\mathrm{C}=\mathbf{0}$ & $\begin{array}{l}\text { OR bruto } \\
\text { (IC 95\%) }\end{array}$ \\
\hline Sexo & & & & & & \\
\hline masculino & 6307 & 6176 & 1,00 & 782 & 370 & 1,00 \\
\hline feminino & 6284 & 7149 & $\begin{array}{c}0,86(0,82 ; 0,90) \\
\mathrm{p}<0,001\end{array}$ & 771 & 454 & $\begin{array}{c}0,80(0,68 ; 0,96) \\
p=0,011\end{array}$ \\
\hline Grupo étnico & & & & & & \\
\hline não negros & 5992 & 6867 & 1,00 & 614 & 342 & 1,00 \\
\hline negros e pardos & 6599 & 6458 & $\begin{array}{c}1,17(1,11 ; 1,23) \\
p<0,001\end{array}$ & 939 & 482 & $\begin{array}{c}1,09(0,91 ; 1,29) \\
\mathrm{p}=0,352\end{array}$ \\
\hline $\begin{array}{r}\text { Tipo de escola } \\
\text { privada }\end{array}$ & 264 & 1104 & 1,00 & 35 & 27 & 1,00 \\
\hline pública & 12327 & 12221 & $\begin{array}{c}4,22(3,67 ; 4,85) \\
p<0,001\end{array}$ & 1518 & 797 & $\begin{array}{c}1,47(0,86 ; 2,51) \\
p=0,136\end{array}$ \\
\hline
\end{tabular}

O modelo multinível de análise multivariada de regressão logística ajustou as variáveis explicativas para a prevalência da necessidade de tratamento odontológico na dentição decídua (Tabela 6.2.5). Ser negro ou pardo (OR ajustada $=1,28)$, estudar na área rural $(\mathrm{OR}$ ajustada $=1,87)$ e em escola pública $(\mathrm{OR}$ ajustada $=3,34)$ foram identificados como determinantes individuais de chance mais elevada de apresentar um ou mais dente decíduo com cárie não tratada na faixa etária de 5 a 7 anos, independente das demais exposições. Ser do sexo feminino $(\mathrm{OR}$ ajustada $=0,82)$ foi identificado como fator de proteção para essa condição. Os coeficientes negativos obtidos para as variáveis independentes do segundo nível indicaram que o perfil de saúde bucal das cidades participantes se beneficiou de valores mais elevados de IDH$M(\beta=-0,49)$ e da adição de flúor à rede de águas $(\beta=-0,32)$. Assim, estas condições foram reconhecidas como determinantes contextuais da prevalência da necessidade de tratamento odontológico na dentição decídua no estado de São Paulo. 
Como o modelo completo apresentou medida de qualidade do ajuste ( $-2 \log$ likelihood) significantemente mais reduzida do que a medida correspondente para o primeiro nível, considerou-se o modelo final (compreendendo todo o conjunto de variáveis explicativas) como sendo o mais efetivo para explicar a variação da condição estudada.

Tabela 6.2.5. Modelo multinível de análise multivariada de regressão logística para a prevalência de cárie não tratada, crianças de 5 a 7 anos de idade, Estado de São Paulo, Brasil, 1998.

\begin{tabular}{|c|c|c|c|c|c|}
\hline Primeiro nível: pessoas & Estimativa & EP & $\begin{array}{c}\text { OR } \\
\text { ajustada }\end{array}$ & IC $(95 \%)$ & $p^{1}$ \\
\hline \multicolumn{6}{|l|}{ Sexo } \\
\hline $\begin{array}{r}{ }^{*} \text { masculino } \\
\text { feminino }\end{array}$ & $-0,198$ & 0,026 & $\begin{array}{l}1,000 \\
0,820\end{array}$ & 0,779 a 0,863 & $\mathrm{p}<0,001$ \\
\hline \multicolumn{6}{|l|}{ Grupo étnico } \\
\hline *não negros & & & 1,000 & & \\
\hline negros e pardos & 0,248 & 0,026 & 1,281 & 1,217 a 1,349 & $\mathrm{p}<0,001$ \\
\hline \multicolumn{6}{|l|}{ Área: rural } \\
\hline $\begin{array}{r}* \text { urbana } \\
\text { rural }\end{array}$ & 0,627 & 0,051 & $\begin{array}{l}1,000 \\
1,873\end{array}$ & 1,694 a 2,070 & $\mathrm{p}<0,001$ \\
\hline \multicolumn{6}{|l|}{ Tipo de escola } \\
\hline $\begin{array}{l}\text { *privada } \\
\text { pública }\end{array}$ & 1,207 & 0,059 & $\begin{array}{l}1,000 \\
3,344\end{array}$ & 2,978 a 3,755 & $\mathrm{p}<0,001$ \\
\hline $\begin{array}{l}\text {-2 log likelihood } \\
\text { (primeiro nível) }\end{array}$ & $33.099,860$ & & & & \\
\hline Segundo nível: cidades & Estimativa & EP & $\boldsymbol{\beta}$ & $\mathbf{p}^{2}$ & \\
\hline Constante (parte fixa) & 1,437 & 0,181 & - & $\mathrm{p}<0,001$ & \\
\hline Índice de & $-1,646$ & 0,235 & $-0,489$ & $\mathrm{p}<0,001$ & \\
\hline \multicolumn{6}{|l|}{ Desenvolvimento } \\
\hline \multicolumn{6}{|l|}{ Humano Municipal } \\
\hline $\begin{array}{l}\text { Fluoretação do sistema } \\
\text { de abastecimento de } \\
\text { água }\end{array}$ & $-0,086$ & 0,019 & $-0,318$ & $\mathrm{p}<0,001$ & \\
\hline \multicolumn{6}{|l|}{$\begin{array}{l}-2 \text { log likelihood } \\
\text { (modelo completo) }\end{array}$} \\
\hline \multicolumn{6}{|l|}{$\mathbf{p}<0,001$} \\
\hline $\begin{array}{l}\text { EP = erro padrão } \\
\text { OR = odds ratio (razão de ch } \\
\beta=\text { coeficiente ajustado } \\
\mathrm{p}^{1}=\text { teste de Wald } \\
\mathrm{p}^{2}=\text { teste t-student } \\
* \text { grupo de referência }\end{array}$ & ances) & & & & \\
\hline
\end{tabular}


O modelo multinível de análise multivariada de regressão logística também foi utilizado para ajustar as variáveis explicativas para a prevalência da necessidade de tratamento odontológico na dentição permanente (Tabela 6.2.6). Foram identificados como fatores associados à cárie não tratada na faixa etária de 10 a 12 anos, ser negro ou pardo $(\mathrm{OR}$ ajustada $=1,11)$, estudar na área rural $(\mathrm{OR}$ ajustada $=$ $1,93)$ e em escola pública $($ OR ajustada $=3,87)$. Ser do sexo feminino $($ OR ajustada $=$ 0,85) foi identificado como fator de proteção para a condição estudada. O coeficiente negativo obtido para a variável independente do segundo nível indica que o perfil de saúde bucal das cidades participantes se beneficiou de valores mais elevados de IDH$M(\beta=-0,49)$, repetindo o que havíamos observado para a dentição decídua. Assim, esta condição foi reconhecida como determinante contextual da prevalência da necessidade de tratamento odontológico tanto na dentição decídua quanto na dentição permanente em escolares do estado de São Paulo. Como o modelo completo apresentou medida de qualidade do ajuste ( $-2 \log$ likelihood) significantemente mais reduzida do que a medida correspondente para o primeiro nível, considerou-se o modelo final (compreendendo todo o conjunto de variáveis explicativas) como sendo o mais efetivo para explicar a variação da condição estudada. 
Tabela 6.2.6. Modelo multinível de análise multivariada de regressão logística para a prevalência de cárie não tratada, escolares de 10 a 12 anos de idade, Estado de São Paulo, 1998.

\begin{tabular}{|c|c|c|c|c|c|}
\hline Primeiro nível: pessoas & Estimativa & EP & $\begin{array}{c}\text { OR } \\
\text { ajustada }\end{array}$ & IC (95\%) & Significância \\
\hline \multicolumn{6}{|l|}{ Sexo } \\
\hline $\begin{array}{r}* \text { masculino } \\
\text { feminino }\end{array}$ & $-0,160$ & 0,024 & $\begin{array}{l}1,000 \\
0,852\end{array}$ & 0,813 a 0,893 & $\mathrm{p}<0,001$ \\
\hline \multicolumn{6}{|l|}{ Grupo étnico } \\
\hline $\begin{array}{r}\text { *não negros } \\
\text { negros e pardos }\end{array}$ & 0,104 & 0,024 & $\begin{array}{l}1,000 \\
1,110\end{array}$ & 1,058 a 1,164 & $\mathrm{p}<0,001$ \\
\hline $\begin{array}{r}\text { Area } \\
* \text { urbana } \\
\text { rural }\end{array}$ & 0,658 & 0,045 & $\begin{array}{l}1,000 \\
1,930\end{array}$ & 1,766 a 2,109 & $\mathrm{p}<0,001$ \\
\hline \multicolumn{6}{|l|}{ Tipo de escola } \\
\hline $\begin{array}{l}\text { *privada } \\
\text { pública }\end{array}$ & 1,353 & 0,067 & $\begin{array}{l}1,000 \\
3,868\end{array}$ & 3,395 a 4,407 & $\mathrm{p}<0,001$ \\
\hline $\begin{array}{l}\text {-2 log likelihood } \\
\text { (primeiro nível) }\end{array}$ & $38.390,951$ & & & & \\
\hline Segundo nível: cidades & Estimativa & EP & $\boldsymbol{\beta}$ & Significância & \\
\hline Constante (parte fixa) & 1,382 & 0,227 & - & $\mathrm{p}<0,001$ & \\
\hline $\begin{array}{l}\text { Índice de } \\
\text { Desenvolvimento }\end{array}$ & $-1,842$ & 0,291 & $-0,486$ & $\mathrm{p}<0,001$ & \\
\hline $\begin{array}{l}\text { Humano Municipal } \\
-2 \text { log likelihood } \\
\text { (modelo completo) }\end{array}$ & $36.663,468$ & & & & \\
\hline \multicolumn{6}{|l|}{$\mathrm{p}<0,001$} \\
\hline $\begin{array}{l}\text { EP }=\text { erro padrão } \\
\mathrm{OR}=\text { odds ratio (razão de cha } \\
3=\text { coeficiente ajustado } \\
\mathrm{O}^{1}=\text { teste de Wald } \\
\mathrm{p}^{2}=\text { teste } \mathrm{t} \text {-student } \\
\\
\text { grupo de referência }\end{array}$ & nces) & & & & \\
\hline
\end{tabular}

\section{3. Condições gengivais}

\subsubsection{Presença de sangramento gengival à sondagem}

Os escolares da área rural do estado apresentaram maior prevalência de sangramento gengival à sondagem que aqueles da área urbana nas duas faixas etárias estudadas. Na faixa etária de 5 a 7 anos $46 \%$ das crianças que estudavam em escolas 
rurais apresentavam sangramento à sondagem (Tabela 6.3.1.1). Na mesma área, 65\% dos escolares de 10 a 12 anos possuíam condição gengival não sadia (Tabela 6.3.1.2). Comparando essas proporções àquelas verificadas entre escolares de áreas urbanas verificamos que essas diferenças mostraram-se estatisticamente significativas $(\mathrm{p}<0,001)$.

Tabela 6.3.1.1 Distribuição dos escolares de 5 a 7 anos de áreas urbanas e rurais, segundo a prevalência de sangramento gengival a sondagem (CPI $\geq 1)$ Estado de São Paulo, 1998.

\begin{tabular}{|c|c|c|c|c|c|}
\hline \multirow[t]{2}{*}{ Área } & \multicolumn{2}{|c|}{$\mathrm{CPI}=0$} & \multicolumn{2}{|c|}{$\mathrm{CPI} \geq 1$} & \multirow{2}{*}{$\begin{array}{l}\text { OR bruto } \\
\text { (IC 95\%) }\end{array}$} \\
\hline & $\mathbf{N}$ & $\%$ & $\overline{\mathbf{N}}$ & $\%$ & \\
\hline Urbana & 16777 & 73,80 & 5956 & 26,20 & 1,00 \\
\hline \multirow[t]{2}{*}{ Rural } & 1091 & 54,25 & 920 & 45,75 & $2,38(2,16 ; 2,61)$ \\
\hline & & & & & $\mathrm{p}<0,001$ \\
\hline
\end{tabular}

Tabela 6.3.1.2 Distribuição dos escolares de 5 a 7 anos de áreas urbanas e rurais, segundo a prevalência de sangramento gengival a sondagem (CPI $\geq 1)$ Estado de São Paulo, 1998.

\begin{tabular}{|c|c|c|c|c|c|}
\hline \multirow[t]{2}{*}{ Área } & \multicolumn{2}{|c|}{$\mathrm{CPI}=0$} & \multicolumn{2}{|c|}{$\mathrm{CPI} \geq 1$} & \multirow{2}{*}{$\begin{array}{l}\text { OR bruto } \\
\text { (IC 95\%) }\end{array}$} \\
\hline & $\mathbf{N}$ & $\%$ & $\mathbf{N}$ & $\%$ & \\
\hline Urbana & 14742 & 56,88 & 11174 & 43,12 & 1,00 \\
\hline \multirow[t]{2}{*}{ Rural } & 843 & 35,46 & 1534 & 64,54 & $2,40(2,20 ; 2,62)$ \\
\hline & & & & & $\mathrm{p}<0,001$ \\
\hline
\end{tabular}

Foram analisadas as condições sócio-demográficas que poderiam estar associadas à presença de sangramento após a sondagem na dentição decídua. 
Apresentaram maior prevalência de sangramento gengival crianças negras e pardas (em relação aos brancos) tanto em áreas urbanas como rurais. Pertencer ao sexo feminino estava associado à menor prevalência da condição estudada nas duas áreas, no entanto, essa associação não se mostrou estatisticamente significativas entre escolares de áreas urbanas do Estado de São Paulo. Estudar em escola pública foi considerado fator de risco para as crianças de áreas urbanas $(\mathrm{OR} 1,53)$ e fator de proteção para as de áreas rurais (OR 0,61), entretanto em relação à última exposição, a associação não se mostrou estatisticamente significativa (Tabela 6.3.1.1.).

Tabela 6.3.1.3. Distribuição de escolares de 5 a 7 anos de áreas urbanas e rurais, segundo a prevalência de sangramento gengival à sondagem $(\mathrm{CPI} \geq 1)$ e características sócio-demográficas, Estado de São Paulo, Brasil, 1998.

\begin{tabular}{|c|c|c|c|c|c|c|}
\hline \multirow[b]{2}{*}{ Condição } & \multicolumn{3}{|c|}{$\begin{array}{c}\text { Urbana } \\
(n=22733)\end{array}$} & \multicolumn{3}{|c|}{$\begin{array}{c}\text { Rural } \\
(n=2011)\end{array}$} \\
\hline & $\mathrm{CPI} \geq 1$ & $\mathrm{CPI}=\mathbf{0}$ & $\begin{array}{c}\text { OR bruto } \\
\text { (IC 95\%) }\end{array}$ & $\mathrm{CPI} \geq 1$ & $\mathrm{CPI}=\mathbf{0}$ & $\begin{array}{l}\text { OR bruto } \\
\text { (IC 95\%) }\end{array}$ \\
\hline \multicolumn{7}{|l|}{ Sexo } \\
\hline masculino & 3068 & 8476 & 1,00 & 499 & 532 & 1,00 \\
\hline feminino & 2888 & 8301 & $\begin{array}{c}0,96(0,91 ; 1,02) \\
p=0,189\end{array}$ & 421 & 559 & $\begin{array}{c}0,80(0,68 ; 0,96) \\
p=0,011\end{array}$ \\
\hline \multicolumn{7}{|l|}{ Grupo étnico } \\
\hline não negros & 2465 & 9776 & 1,00 & 379 & 518 & 1,00 \\
\hline negros e pardos & 3491 & 7001 & $\begin{array}{c}1,98(1,86 ; 2,10) \\
\mathrm{p}<0,001\end{array}$ & 541 & 573 & $\begin{array}{c}1,29(1,08 ; 1,55) \\
p=0,004\end{array}$ \\
\hline \multicolumn{7}{|l|}{ Tipo de escola } \\
\hline privada & 288 & 1211 & 1,00 & 22 & 16 & 1,00 \\
\hline pública & 5668 & 15566 & $\begin{array}{c}1,53(1,34 ; 1,75) \\
p<0,001\end{array}$ & 898 & 1075 & $\begin{array}{c}0,61(0,30 ; 1,21) \\
p=0,129\end{array}$ \\
\hline
\end{tabular}

As mesmas variáveis sócio-demográficas foram testadas para sangramento gengival à sondagem em dentes permanentes. Na faixa etária estudada (10 a 12 anos) 
entre escolares da área urbana, ser do sexo masculino, ser negro ou pardo e freqüentar escola pública mostrou-se associado à presença de sangramento gengival à sondagem, sendo essa associação estatisticamente significativa. Analisando as mesmas exposições entre escolares de área rural, não verificamos associação entre sexo e sangramento gengival à sondagem, enquanto que, ser negro ou pardo e freqüentar escola pública mostraram-se associados à presença de sangramento gengival à sondagem de forma estatisticamente significativa, sendo que freqüentar escola pública comportou-se como fator protetor (Tabela 6.3.1.2.).

Tabela 6.3.1.4. Distribuição de escolares de 10 a 12 anos de áreas urbanas e rurais, segundo a prevalência de sangramento gengival à sondagem $(\mathrm{CPI} \geq 1)$ e características sócio-demográficas, Estado de São Paulo, Brasil, 1998.

\begin{tabular}{|c|c|c|c|c|c|c|}
\hline \multirow[b]{2}{*}{ Condição } & \multicolumn{3}{|c|}{$\begin{array}{c}\text { Urbana } \\
(n=25916)\end{array}$} & \multicolumn{3}{|c|}{$\begin{array}{c}\text { Rural } \\
(n=2377)\end{array}$} \\
\hline & $\mathrm{CPI} \geq 1$ & $\mathrm{CPI}=0$ & $\begin{array}{c}\text { OR bruto } \\
\text { (IC 95\%) }\end{array}$ & $\mathrm{CPI} \geq 1$ & $\mathrm{CPI}=0$ & $\begin{array}{c}\text { OR bruto } \\
\text { (IC 95\%) }\end{array}$ \\
\hline \multicolumn{7}{|l|}{ Sexo } \\
\hline masculino & 5675 & 6808 & 1,00 & 747 & 405 & 1,00 \\
\hline feminino & 5499 & 7934 & $\begin{array}{c}0,83(0,79 ; 0,87) \\
\mathrm{p}<0,001\end{array}$ & 787 & 438 & $\begin{array}{c}0,97(0,82 ; 1,16) \\
p=0,760\end{array}$ \\
\hline \multicolumn{7}{|l|}{ Grupo étnico } \\
\hline não negros & 4403 & 8456 & 1,00 & 552 & 404 & 1,00 \\
\hline negros e pardos & 6771 & 6286 & $\begin{array}{c}2,07(1,97 ; 2,18) \\
\mathrm{p}<0,001\end{array}$ & 982 & 439 & $\begin{array}{c}1,64(1,38 ; 1,95) \\
\mathrm{p}<0,001\end{array}$ \\
\hline \multicolumn{7}{|l|}{ Tipo de escola } \\
\hline privada & 513 & 855 & 1,00 & 51 & 11 & 1,00 \\
\hline pública & 10661 & 13887 & $\begin{array}{c}1,28(1,14 ; 1,43) \\
p<0,001\end{array}$ & 1483 & 832 & $\begin{array}{c}0,38(0,19 ; 0,77) \\
p=0,003\end{array}$ \\
\hline
\end{tabular}

O modelo multinível de análise multivariada de regressão logística ajustou as variáveis explicativas para sangramento gengival à sondagem na dentição decídua 
(Tabela 6.3.1.3.). Na faixa etária de 5 a 7 anos, ser negro ou pardo (OR ajustada $=$ 1,87), estudar na área rural (OR ajustada $=2,26)$ e em escola pública (OR ajustada $=$ 1,30) mostraram-se como determinantes individuais associados ao desfecho de interesse independentemente das demais. Ser do sexo feminino $(\mathrm{OR}$ ajustada $=0,95)$ foi identificado como fator de proteção para essa condição. No segundo nível, manteve-se no modelo apenas o Índice de Cuidado (IC), cujo coeficiente negativo indica que uma prevalência mais elevada de condição gengival saudável tendeu a ser observado nas cidades que se beneficiaram de um acesso mais elevado a tratamento odontológico $(\beta=-0,14)$. Sendo reconhecida como determinante contextual de sangramento gengival à sondagem da dentição decídua no Estado de São Paulo. Como o modelo completo apresentou medida de qualidade do ajuste $(-2 \log$ likelihood) significantemente mais reduzida que a medida correspondente para o primeiro nível, considerou-se o modelo final (compreendendo todo o conjunto de variáveis explicativas) como sendo o mais efetivo para explicar a variação da condição estudada. 
Tabela 6.3.1.5 Modelo multinível de análise multivariada de regressão logística para a prevalência de sangramento gengival durante sondagem, crianças de 5 a 7 anos de idade, Estado de São Paulo, 1998.

\begin{tabular}{|c|c|c|c|c|c|}
\hline $\begin{array}{c}\text { Primeiro nível: } \\
\text { pessoas }\end{array}$ & Estimativa & EP & $\begin{array}{c}\text { OR } \\
\text { ajustada }\end{array}$ & IC (95\%) & $p^{1}$ \\
\hline $\begin{array}{l}\text { Sexo } \\
* \text { masculino } \\
\text { feminino }\end{array}$ & $-0,049$ & 0,029 & $\begin{array}{l}1,000 \\
0,952\end{array}$ & 0,899 a 1,007 & $\mathrm{p}=0,088$ \\
\hline $\begin{array}{l}\text { Grupo étnico } \\
\text { não negros } \\
\text { negros e pardos }\end{array}$ & 0,627 & 0,029 & $\begin{array}{l}1,000 \\
1,871\end{array}$ & 1,767 a 1,981 & $\mathrm{p}<0,001$ \\
\hline $\begin{array}{r}* \text { urbana } \\
\text { rural } \\
\text { Tino de escola }\end{array}$ & 0,815 & 0,048 & $\begin{array}{l}1,000 \\
2,260\end{array}$ & 2,057 a 2,482 & $\mathrm{p}<0,001$ \\
\hline $\begin{array}{r}\text { *privada } \\
\text { pública } \\
\text {-2 log likelihood } \\
\text { (primeiro nível) } \\
\end{array}$ & $\begin{array}{c}0,265 \\
28.410,754\end{array}$ & 0,066 & $\begin{array}{l}1,000 \\
1,303\end{array}$ & 1,144 a 1,483 & $\mathrm{p}=0,001$ \\
\hline $\begin{array}{l}\text { Segundo nível: } \\
\text { cidades }\end{array}$ & Estimativa & EP & $\boldsymbol{\beta}$ & $\mathbf{p}^{2}$ & \\
\hline $\begin{array}{l}\text { Constante (parte } \\
\text { fixa) }\end{array}$ & 0,097 & 0,045 & - & $\mathrm{p}=0,033$ & \\
\hline $\begin{array}{l}\text { Índice de Cuidados } \\
\text { Odontológicos }\end{array}$ & $-0,002$ & 0,001 & $-0,139$ & $\mathrm{p}=0,114$ & \\
\hline $\begin{array}{c}-2 \text { log likelihood } \\
\text { (modelo completo) }\end{array}$ & $28.140,666$ & & & & \\
\hline $\begin{array}{l}\mathbf{p}<\mathbf{0 , 0 0 1} \\
\text { EP = erro padrão } \\
\text { OR = odds ratio (razão de c } \\
\beta=\text { coeficiente ajustado } \\
\mathrm{p}^{1}=\text { teste de Wald } \\
\mathrm{p}^{2}=\text { teste } \mathrm{t} \text {-student } \\
* \text { grupo de referência }\end{array}$ & hances) & & & & \\
\hline
\end{tabular}

Visando ajustar as variáveis explicativas para sangramento gengival à sondagem na dentição permanente, o modelo multinível de análise multivariada de regressão logística foi novamente utilizado (Tabela 6.3.1.4). Foram identificados como fatores individuais associados ao sangramento gengival à sondagem, ser negro 
ou pardo $(\mathrm{OR}$ ajustada $=2,03)$ e estudar na área rural $(\mathrm{OR}$ ajustada $=2,30)$. Estar matriculado em escola pública $(\mathrm{OR}$ ajustada $=1,05)$ perdeu significância estatística. Ser do sexo feminino $(\mathrm{OR}$ ajustada $=0,83)$ foi identificado como fator de proteção para a condição gengival estudada. $\mathrm{O}$ coeficiente negativo obtido para a variável independente do segundo nível indica que o perfil de saúde bucal das cidades participantes se beneficiou de valores mais elevados de Índice de Cuidado (IC) ( $\beta=-$ 0,28), em observação análoga à que havia sido efetuada para a dentição decídua. Assim, esta condição foi reconhecida como determinante contextual de sangramento gengival à sondagem tanto na dentição decídua quanto na dentição permanente em escolares do Estado de São Paulo. Como o modelo completo apresentou medida de qualidade do ajuste ( $-2 \log$ likelihood) significantemente mais reduzida que a medida correspondente para o primeiro nível, considerou-se o modelo final (compreendendo todo o conjunto de variáveis explicativas) como sendo o mais efetivo para explicar a variação da condição estudada. 
Tabela 6.3.1.6. Modelo multinível de análise multivariada de regressão logística para a prevalência de sangramento gengival durante sondagem, crianças de 10 a 12 anos de idade, Estado de São Paulo, 1998.

\begin{tabular}{|c|c|c|c|c|c|}
\hline $\begin{array}{c}\text { Primeiro nível: } \\
\text { pessoas }\end{array}$ & Estimativa & $\mathbf{E P}$ & $\begin{array}{c}\text { OR } \\
\text { ajustada }\end{array}$ & IC (95\%) & Significância \\
\hline \multicolumn{6}{|l|}{ Sexo } \\
\hline $\begin{array}{r}* \text { masculino } \\
\text { feminino }\end{array}$ & $-0,177$ & 0,025 & $\begin{array}{l}1,000 \\
0,838\end{array}$ & 0,799 a 0,879 & $\mathrm{p}<0,001$ \\
\hline \multicolumn{6}{|l|}{ Grupo étnico } \\
\hline $\begin{array}{r}\text { *não negros } \\
\text { negros e pardos }\end{array}$ & 0,707 & 0,025 & $\begin{array}{l}1,003 \\
2,029\end{array}$ & 1,933 a 2,129 & $\mathrm{p}<0,001$ \\
\hline \multicolumn{6}{|l|}{ Área } \\
\hline $\begin{array}{r}* \text { urbana } \\
\text { rural } \\
\text { Tipo de escola }\end{array}$ & 0,834 & 0,045 & $\begin{array}{l}1,000 \\
2,303\end{array}$ & 2,107 a 2,517 & $\mathrm{p}<0,001$ \\
\hline $\begin{array}{r}\text { *privada } \\
\text { pública } \\
\text {-2 log likelihood } \\
\text { (primeiro nível) } \\
\end{array}$ & $\begin{array}{c}0,050 \\
37.622,742\end{array}$ & 0,057 & $\begin{array}{l}1,000 \\
1,051\end{array}$ & 0,940 a 1,175 & $\mathrm{p}=0,382$ \\
\hline $\begin{array}{c}\text { Segundo nível: } \\
\text { cidades }\end{array}$ & Estimativa & $\mathbf{E P}$ & $\boldsymbol{\beta}$ & Significância & \\
\hline $\begin{array}{l}\text { Constante (parte } \\
\text { fixa) }\end{array}$ & 0,369 & 0,067 & - & $\mathrm{p}<0,001$ & \\
\hline $\begin{array}{l}\text { Índice de Cuidados } \\
\text { Odontológicos }\end{array}$ & $-0,004$ & 0,001 & $-0,284$ & $\mathrm{p}=0,001$ & \\
\hline $\begin{array}{c}\text {-2 log likelihood } \\
\text { (modelo completo) }\end{array}$ & $36.902,322$ & & & & \\
\hline $\mathrm{p}<0,001$ & & & & & \\
\hline 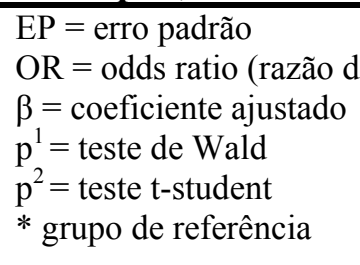 & chances) & & & & \\
\hline
\end{tabular}

\subsubsection{Presença de cálculo dental visível}

Os escolares de áreas rurais, em relação àqueles de áreas urbanas, apresentaram maior prevalência de cálculo dental visível e menor prevalência de 
condição gengival sadia ou apenas com sangramento à sondagem, nas duas faixas etárias estudadas, sendo que a análise comparativa entre esses dois grupos de escolares mostrou-se estatisticamente significativa $(\mathrm{p}<0,01)$ (Tabela 6.3.2.1 e Tabela 6.3.2.2). Cálculo dental foi observado em $6 \%$ das crianças de 5 a 7 anos de áreas rurais do Estado (Tabela 6.3.2.1).

Tabela 6.3.2.1 Número e porcentagem de presença $(\mathrm{CPI}=2)$ ou não $(\mathrm{CPI} \leq 1)$ de cálculo dentário visível em escolares de 5 a 7 anos de áreas urbanas e rurais, Estado de São Paulo, 1998.

\begin{tabular}{|c|c|c|c|c|c|}
\hline \multirow[t]{2}{*}{ Área } & \multicolumn{2}{|c|}{$\mathrm{CPI} \leq 1$} & \multicolumn{2}{|c|}{$\mathrm{CPI}=2$} & \multirow{2}{*}{$\begin{array}{l}\text { OR bruto } \\
\text { (IC 95\%) }\end{array}$} \\
\hline & $\mathbf{N}$ & $\%$ & $\mathbf{N}$ & $\%$ & \\
\hline Urbana & 22045 & 96,97 & 688 & 3,03 & 1,00 \\
\hline \multirow[t]{2}{*}{ Rural } & 1885 & 93,73 & 126 & 6,27 & $2,14(1,75 ; 2,64)$ \\
\hline & & & & & $\mathrm{p}<0,001$ \\
\hline
\end{tabular}

OR $=$ odds ratio (razão de chances)

$\mathrm{IC}=$ Intervalo de confiança

$\mathrm{p}=$ valores de $\mathrm{p}$ calculados pelo teste qui-quadrado

$\mathrm{Na}$ faixa etária de 10 a 12 anos, 24\% dos alunos de escolas rurais apresentaram cálculo visível nos dentes. $\mathrm{Na}$ área urbana essa porcentagem foi de $13 \%$, sendo que a análise comparativa entre esses dois grupos de escolares mostrouse estatisticamente significativa $(\mathrm{p}<0,01)$ (Tabela 6.3.2.2). 
Tabela 6.3.2.2. Número e porcentagem de presença $(\mathrm{CPI}=2)$ ou não $(\mathrm{CPI} \leq 1)$ de cálculo dentário visível em escolares de 10 a 12 anos de áreas urbanas e rurais, Estado de São Paulo, 1998.

\begin{tabular}{|c|c|c|c|c|c|}
\hline \multirow[t]{2}{*}{ Área } & \multicolumn{2}{|c|}{$\mathrm{CPI} \leq 1$} & \multicolumn{2}{|c|}{$\mathrm{CPI}=2$} & \multirow{2}{*}{$\begin{array}{l}\text { OR bruto } \\
\text { (IC 95\%) }\end{array}$} \\
\hline & $\mathbf{N}$ & $\%$ & $\mathbf{N}$ & $\%$ & \\
\hline Urbana & 22466 & 86,69 & 3450 & 13,31 & 1,00 \\
\hline \multirow[t]{2}{*}{ Rural } & 1816 & 76,40 & 561 & 23,60 & $2,01(1,82 ; 2,23)$ \\
\hline & & & & & $\mathrm{p}<0,001$ \\
\hline
\end{tabular}

As mesmas condições sócio-demográficas testadas para os agravos analisados anteriormente foram testadas quanto à associação com presença de cálculo visível na dentição decídua. Na faixa etária de 5 a 7 anos, ser negro ou pardo (em relação aos brancos) e freqüentar escola pública (em relação às privadas) mostraram-se associados à presença de cálculo dentário, tanto em áreas urbanas como rurais, sendo que freqüentar escola pública mostrou-se como fator de proteção na área rural. Essas associações mostraram-se estatisticamente significativas, ainda que freqüentar escola pública em área urbana situou-se em situação limítrofe. Com referência a presença de cálculo dental, não se identificou associação com o sexo (Tabela 6.3.2.3.). 
Tabela 6.3.2.3 Distribuição de escolares de 5 a 7 anos de áreas urbanas e rurais, segundo a prevalência de cálculo dental visível $(\mathrm{CPI}=2)$ e características sócio-demográficas, Estado de São Paulo, Brasil, 1998.

\begin{tabular}{|c|c|c|c|c|c|c|}
\hline \multirow[b]{2}{*}{ Condição } & \multicolumn{3}{|c|}{$\begin{array}{c}\text { Urbana } \\
(\mathrm{n}=\mathbf{2 2 7 3 3 )}\end{array}$} & \multicolumn{3}{|c|}{$\begin{array}{c}\text { Rural } \\
(n=2011)\end{array}$} \\
\hline & $\mathrm{CPI} \leq 1$ & $\mathrm{CPI}=2$ & $\begin{array}{c}\text { OR bruto } \\
\text { (IC 95\%) }\end{array}$ & $\mathrm{CPI} \leq 1$ & $\mathrm{CPI}=2$ & $\begin{array}{c}\text { OR bruto } \\
\left.\text { (IC }{ }_{95 \%}\right)\end{array}$ \\
\hline \multicolumn{7}{|l|}{ Sexo } \\
\hline masculino & 11177 & 367 & 1,00 & 966 & 65 & 1,00 \\
\hline feminino & 10868 & 321 & $\begin{array}{c}0,90(0,77 ; 1,05) \\
\mathrm{p}=0,172\end{array}$ & 919 & 61 & $\begin{array}{c}0,99(0,68 ; 1,44) \\
\mathrm{p}=0,941\end{array}$ \\
\hline \multicolumn{7}{|l|}{ Grupo étnico } \\
\hline não negros & 12002 & 239 & 1,00 & 865 & 32 & 1,00 \\
\hline negros e pardos & 10043 & 449 & $\begin{array}{c}2,25(1,91 ; 2,64) \\
\mathrm{p}<0,001\end{array}$ & 1020 & 94 & $\begin{array}{c}2,49(1,62 ; 3,84) \\
\mathrm{p}<0,001\end{array}$ \\
\hline \multicolumn{7}{|l|}{ Tipo de escola } \\
\hline privada & 1466 & 33 & 1,00 & 32 & 6 & 1,00 \\
\hline pública & 20579 & 655 & $\begin{array}{c}1,41(0,98 ; 2,05) \\
p=0,054\end{array}$ & 1853 & 120 & $\begin{array}{c}0,35(0,13 ; 0,94) \\
\text { p } 0,035\end{array}$ \\
\hline
\end{tabular}

As condições sócio-demográficas que poderiam estar associadas com a presença de cálculo dental também foram analisadas na faixa etária de 10 a 12 anos. Tanto em áreas urbanas como rurais, ser negro ou pardo mostrou-se associado ao cálculo dental, essas associações foram estatisticamente significativas. Ser do sexo feminino apresentou-se como fator de proteção Freqüentar escola pública mostrou-se associado ao cálculo dental, sendo que essa associação foi estatisticamente significativa somente para áreas urbanas (Tabela 6.3.2.4). 
Tabela 6.3.2.4. Distribuição de escolares de 10 a 12 anos de áreas urbanas e rurais, segundo a prevalência de cálculo dental visível (CPI=2) e características sócio-demográficas, Estado de São Paulo, Brasil, 1998.

\begin{tabular}{|c|c|c|c|c|c|c|}
\hline \multirow[b]{2}{*}{ Condição } & \multicolumn{3}{|c|}{$\begin{array}{c}\text { Urbana } \\
(\mathrm{n}=25916)\end{array}$} & \multicolumn{3}{|c|}{$\begin{array}{c}\text { Rural } \\
(\mathrm{n}=\mathbf{2 3 7 7})\end{array}$} \\
\hline & $\mathrm{CPI} \leq 1$ & $\mathrm{CPI}=2$ & $\begin{array}{c}\text { OR bruto } \\
\text { (IC 95\%) }\end{array}$ & $\mathrm{CPI} \leq 1$ & $\mathrm{CPI}=2$ & $\begin{array}{c}\text { OR bruto } \\
\text { (IC 95\%) }\end{array}$ \\
\hline \multicolumn{7}{|l|}{ Sexo } \\
\hline masculino & 10646 & 1837 & 1,00 & 853 & 299 & 1,00 \\
\hline feminino & 11820 & 1613 & $\begin{array}{c}0,79(0,74 ; 0,85) \\
\mathrm{p}<0,001\end{array}$ & 963 & 262 & $\begin{array}{c}1,29(1,06 ; 1,56) \\
p=0,009\end{array}$ \\
\hline \multicolumn{7}{|l|}{ Grupo étnico } \\
\hline não negros & 11632 & 1227 & 1,00 & 812 & 144 & 1,00 \\
\hline negros e pardos & 10834 & 2223 & $\begin{array}{c}1,95(1,80 ; 2,10) \\
\mathrm{p}<0,001\end{array}$ & 1004 & 417 & $\begin{array}{c}2,34(1,89 ; 2,91) \\
\mathrm{p}<0,001\end{array}$ \\
\hline \multicolumn{7}{|l|}{ Tipo de escola } \\
\hline privada & 1234 & 134 & 1,00 & 42 & 20 & 1,00 \\
\hline pública & 21232 & 3316 & $\begin{array}{c}1,44(1,19 ; 1,73) \\
\mathrm{p}<0,001\end{array}$ & 1774 & 541 & $\begin{array}{c}0,64(0,36 ; 1,14) \\
p=0,140\end{array}$ \\
\hline
\end{tabular}

O modelo multinível de análise multivariada de regressão logística ajustou as variáveis explicativas para o cálculo dental na dentição decídua (Tabela 6.3.2.5). Na faixa etária de 5 a 7 anos, ser negro ou pardo (OR ajustada $=2,26)$ e estudar na área rural $(\mathrm{OR}$ ajustada $=1,99)$ foram identificados como fatores individuais associados a presença de cálculo dental visível. No segundo nível, nenhuma variável independente testada manteve-se no modelo, não sendo identificado, portanto, nenhum determinante contextual da prevalência de cálculo dental na dentição decídua no Estado de São Paulo. 
Tabela 6.3.2.5 Análise multivariada de regressão logística para a prevalência de cálculo dental, crianças de 5 a 7 anos de idade, Estado de São Paulo, 1998.

\begin{tabular}{|c|c|c|c|c|c|}
\hline $\begin{array}{l}\text { Primeiro nível: } \\
\text { pessoas }\end{array}$ & Estimativa & EP & $\begin{array}{c}\text { OR } \\
\text { ajustada }\end{array}$ & IC (95\%) & $\mathbf{p}$ \\
\hline \multicolumn{6}{|l|}{ Sexo } \\
\hline $\begin{array}{r}{ }^{*} \text { masculino } \\
\text { feminino }\end{array}$ & $-0,080$ & 0,072 & $\begin{array}{l}1,000 \\
0,923\end{array}$ & 0,802 a 1,062 & $p=0,263$ \\
\hline \multicolumn{6}{|l|}{ Grupo étnico } \\
\hline $\begin{array}{r}\text { *não negros } \\
\text { negros e pardos }\end{array}$ & 0,818 & 0,076 & $\begin{array}{l}1,000 \\
2,266\end{array}$ & 1,952 a 2,630 & $\mathrm{p}<0,001$ \\
\hline $\begin{array}{rr} & * \text { urbana } \\
\text { Tipo de escola } & \end{array}$ & 0,692 & 0,101 & $\begin{array}{l}1,000 \\
1,998\end{array}$ & 1,640 a 2,432 & $\mathrm{p}<0,001$ \\
\hline $\begin{array}{r}\text { privada } \\
\text { pública } \\
\text {-2 log likelihood } \\
\text { (primeiro nível) }\end{array}$ & $\begin{array}{c}0,051 \\
6.982,858\end{array}$ & 0,168 & $\begin{array}{l}1,000 \\
1,052\end{array}$ & 0,757 a 1,462 & $\mathrm{p}=0,762$ \\
\hline $\begin{array}{l}\mathrm{EP}=\text { erro padrão } \\
\mathrm{OR}=\text { odds ratio (razão de ch } \\
\mathrm{IC}=\text { Intervalo de confiança } \\
\text { = teste de Wald } \\
\text { grupo de referência }\end{array}$ & inces) & & & & \\
\hline
\end{tabular}

Para os escolares de 10 a 12 anos também foi utilizado o modelo multinível de análise multivariada de regressão logística para ajustar as variáveis explicativas para a prevalência de cálculo dental na dentição permanente (Tabela 6.3.2.6). Ser negro ou pardo $(\mathrm{OR}$ ajustada $=1,98)$ e estudar na área rural $(\mathrm{OR}$ ajustada $=1,91)$ foram identificados como fatores individuais associados à presença de cálculo dental visível, independentemente das demais exposições. Ser do sexo feminino se apresentou como fator de proteção para a condição estudada $(\mathrm{OR}$ ajustada $=0,79)$. $\mathrm{O}$ coeficiente negativo obtido para a variável independente do segundo nível indica que, também nesse quesito, o perfil de saúde bucal das cidades participantes se beneficiou de valores mais elevados de Índice de Cuidado (IC) $(\beta=-0,17)$. Assim, 
esta condição foi reconhecida como determinante contextual da prevalência de cálculo dental na dentição permanente em escolares do estado de São Paulo. Como o modelo completo apresentou medida de qualidade do ajuste ( $-2 \log$ likelihood) significantemente mais reduzida do que a medida correspondente para o primeiro nível, considerou-se o modelo final (compreendendo todo o conjunto de variáveis explicativas) como sendo o mais efetivo para explicar a variação da condição estudada.

Tabela 6.3.2.6. Modelo multinível de análise multivariada de regressão logística para a prevalência de cálculo dental, crianças de 10 a 12 anos de idade, São Paulo, 1998.

\begin{tabular}{|c|c|c|c|c|c|}
\hline $\begin{array}{l}\text { Primeiro nível: } \\
\text { pessoas }\end{array}$ & Estimativa & EP & $\begin{array}{c}\text { OR } \\
\text { ajustada }\end{array}$ & IC $(95 \%)$ & $p^{1}$ \\
\hline \multicolumn{6}{|l|}{ Sexo } \\
\hline $\begin{array}{r}{ }^{*} \text { masculino } \\
\text { feminino }\end{array}$ & $-0,240$ & 0,035 & $\begin{array}{l}1,000 \\
0,787\end{array}$ & 0,735 a 0,842 & $\mathrm{p}<0,001$ \\
\hline \multicolumn{6}{|l|}{ Grupo étnico } \\
\hline $\begin{array}{r}\text { *não negros } \\
\text { negros e pardos }\end{array}$ & 0,682 & 0,036 & $\begin{array}{l}1,000 \\
1,978\end{array}$ & 1,843 a 2,122 & $\mathrm{p}<0,001$ \\
\hline $\begin{array}{rr}* \text { urbana } \\
\text { rural } \\
\text { Tipo de escola }\end{array}$ & 0,646 & 0,052 & $\begin{array}{l}1,000 \\
1,908\end{array}$ & 1,722 a 2,113 & $\mathrm{p}<0,001$ \\
\hline $\begin{array}{r}\text { *privada } \\
\text { pública } \\
\text {-2 log likelihood } \\
\text { (primeiro nível) } \\
\end{array}$ & $\begin{array}{c}0,151 \\
22.495,610\end{array}$ & 0,088 & $\begin{array}{l}1,000 \\
1,163\end{array}$ & 0,978 a 1,382 & $\mathrm{p}=0,088$ \\
\hline Segundo nível: cidades & Estimativa & EP & $\boldsymbol{\beta}$ & $\mathbf{p}^{2}$ & \\
\hline $\begin{array}{l}\text { Constante (parte fixa) } \\
\text { Índice de Cuidados }\end{array}$ & $\begin{array}{c}0,174 \\
-0,001\end{array}$ & $\begin{array}{l}0,035 \\
0,001\end{array}$ & $-\overline{-}-170$ & $\begin{array}{l}\mathrm{p}<0,001 \\
\mathrm{p}=0,052\end{array}$ & \\
\hline $\begin{array}{l}\text { Odontológicos } \\
\text {-2 log likelihood } \\
\text { (modelo completo) }\end{array}$ & $22.422,866$ & & & & \\
\hline $\mathrm{p}<0,001$ & & & & & \\
\hline $\begin{array}{l}\mathrm{P}=\text { erro padrão } \\
\mathrm{DR}=\text { odds ratio (razão de } \\
=\text { coeficiente ajustado } \\
\hat{1}^{1}=\text { teste de Wald } \\
\hat{2}^{2}=\text { teste } \mathrm{t} \text {-student } \\
\text { grupo de referência }\end{array}$ & hances) & & & & \\
\hline
\end{tabular}




\subsection{Indicadores de saúde bucal em áreas rurais homogêneas}

Nesse item, apresentamos os resultados da análise dos dados agregados em 12 classes rurais do Estado de São Paulo, segundo a categorização descrita no capítulo de Material e Métodos.

\subsubsection{Cárie dentária em áreas rurais homogêneas}

Pode-se observar que todas as áreas rurais do Estado, agrupadas por características socioeconômicas, apresentam elevada prevalência de cárie na dentição decídua. $\mathrm{Na}$ área rural homogênea classificada como número 12 (área de agricultura modernizada) além de a prevalência ser elevada, verificou-se uma reduzida proporção de crianças livres de cárie e de dentes cariados já restaurados (índice de cuidados). A área 10 (área com maior índice de condição de vida), em relação às outras classes, apresentou o maior índice de cuidado e a maior porcentagem de crianças livres de cárie dentária (Tabela 6.4.1.1). 
Tabela 6.4.1.1 Áreas rurais homogêneas de acordo com o índice de cárie (ceo-d), índice de cuidado (IC) e a prevalência de cárie não tratada na dentição decídua. São Paulo, 1998.

\begin{tabular}{cccccccc}
\hline & & & & \multicolumn{2}{c}{$\mathbf{c} \geq \mathbf{1}$} & \multicolumn{2}{c}{$\mathbf{c}=\mathbf{0}$} \\
\cline { 6 - 9 } Classe & $\mathbf{N}$ & $\mathbf{c e o - d}$ & $\mathbf{I C}$ & $\mathbf{N}$ & $\mathbf{\%}$ & $\mathbf{N}$ & $\mathbf{\%}$ \\
\hline $\mathbf{1}$ & 221 & 4,46 & 18,98 & 152 & 68,78 & 69 & 31,22 \\
$\mathbf{2}$ & 181 & 4,86 & 17,52 & 140 & 77,35 & 41 & 22,65 \\
$\mathbf{3}$ & 40 & 3,60 & 21,53 & 24 & 60,00 & 16 & 40,00 \\
$\mathbf{4}$ & 23 & 4,04 & 20,43 & 14 & 60,87 & 9 & 39,13 \\
$\mathbf{5}$ & 209 & 3,85 & 34,45 & 127 & 60,77 & 82 & 39,23 \\
$\mathbf{6}$ & 353 & 4,76 & 15,11 & 263 & 74,50 & 90 & 25,50 \\
$\mathbf{7}$ & 366 & 4,50 & 8,01 & 271 & 74,04 & 95 & 25,96 \\
$\mathbf{8}$ & 132 & 4,93 & 31,03 & 90 & 68,19 & 42 & 31,82 \\
$\mathbf{9}$ & 233 & 5,40 & 34,31 & 164 & 70,39 & 69 & 29,61 \\
$\mathbf{1 0}$ & 33 & 4,00 & 63,64 & 18 & 55,55 & 15 & 45,46 \\
$\mathbf{1 1}$ & 135 & 4,56 & 27,32 & 94 & 69,63 & 41 & 30,37 \\
$\mathbf{1 2}$ & 43 & 7,00 & 19,27 & 33 & 76,74 & 10 & 23,26 \\
\hline
\end{tabular}

Entre as áreas rurais homogêneas, o índice CPO-D variou de 2,07 (classe 10) até 4,28 (classe 1, áreas rurais de agricultura de subsistência). A classe 10 novamente apresentou os melhores indicadores de saúde bucal, menor valor do índice CPO-D $(2,07)$, índice de cuidado elevado $(83,87)$ e $63,67 \%$ dos escolares estavam livres de cárie dentária. Apesar de apresentar um dos valores mais baixos do índice CPO-D $(2,75)$, as áreas rurais classificadas como pertencentes à classe 7 (áreas rurais de agricultura de subsistência) apresentam indicadores de falta de acesso dos escolares a tratamento odontológico $(20 \%$ de Índice de Cuidados e $36 \%$ de crianças livres de cárie não tratada $(\mathrm{C}=0)$ (Tabela 6.4.1.2). 
Tabela 6.4.1.2 Áreas rurais homogêneas de acordo com o índice de cárie (CPO-D), índice de cuidado (IC) e a prevalência de cárie não tratada na dentição permanente. São Paulo, 1998.

\begin{tabular}{cccccccc}
\hline & & & & \multicolumn{2}{c}{$\mathbf{C} \geq \mathbf{1}$} & \multicolumn{2}{c}{$\mathbf{C}=\mathbf{0}$} \\
\cline { 6 - 9 } Classe & $\mathbf{N}$ & CPO-D & IC & N & \% & N & \% \\
\hline $\mathbf{1}$ & 321 & 4,28 & 58,18 & 188 & 58,57 & 133 & 41,43 \\
$\mathbf{2}$ & 177 & 3,76 & 46,70 & 112 & 23,67 & 65 & 36,72 \\
$\mathbf{3}$ & 108 & 2,45 & 50,94 & 57 & 52,78 & 51 & 47,22 \\
$\mathbf{4}$ & 58 & 3,03 & 40,34 & 34 & 58,62 & 24 & 41,38 \\
$\mathbf{5}$ & 353 & 3,19 & 48,98 & 169 & 47,88 & 184 & 52,12 \\
$\mathbf{6}$ & 313 & 3,01 & 34,25 & 178 & 56,87 & 135 & 43,13 \\
$\mathbf{7}$ & 453 & 2,75 & 19,90 & 290 & 64,02 & 163 & 35,98 \\
$\mathbf{8}$ & 110 & 3,34 & 74,11 & 40 & 36,37 & 70 & 63,64 \\
$\mathbf{9}$ & 249 & 3,48 & 64,09 & 116 & 46,59 & 133 & 53,41 \\
$\mathbf{1 0}$ & 30 & 2,07 & 83,87 & 7 & 23,33 & 23 & 76,67 \\
$\mathbf{1 1}$ & 143 & 3,51 & 48,41 & 73 & 51,05 & 70 & 48,95 \\
$\mathbf{1 2}$ & 38 & 3,92 & 93,96 & 8 & 21,05 & 30 & 23,26 \\
\hline
\end{tabular}

A classe rural homogênea classificada como classe 10, tendo apresentado melhores indicadores de saúde bucal foi utilizada para comparação com as demais. As áreas classificadas como classe 7 , em relação as pertencentes à classe 10 , apresentaram índice de cuidado muito inferior, tanto para a dentição decídua (Razão $\mathrm{IC}=0,13$ ) como para a dentição permanente (Razão $\mathrm{IC}=0,24)$. As crianças de 5 a 7 anos da classe 12 possuem índice ceo-d 75\% mais elevado que as da classe 10 . Na faixa etária de 10 a 12 anos, os escolares da classe 1 possuem como média de CPO-D o dobro do valor da média do índice para os escolares da classe 10 (Tabela 6.4.1.3). 
Tabela 6.4.1.3 Razão dos indicadores de saúde bucal utilizando a classe 10 como referência.

São Paulo, 1998.

\begin{tabular}{ccccc}
\hline Classe & $\begin{array}{c}\text { Razão } \\
\text { ceo-d }\end{array}$ & $\begin{array}{c}\text { Razão } \\
\text { IC ceo-d }\end{array}$ & $\begin{array}{c}\text { Razão } \\
\text { CPO-D }\end{array}$ & $\begin{array}{c}\text { Razão } \\
\text { IC CPO-D }\end{array}$ \\
\hline $\mathbf{1}$ & 1,12 & 0,30 & 2,06 & 0,69 \\
$\mathbf{2}$ & 1,22 & 0,28 & 1,82 & 0,56 \\
$\mathbf{3}$ & 0,90 & 0,34 & 1,18 & 0,61 \\
$\mathbf{4}$ & 1,01 & 0,32 & 1,46 & 0,48 \\
$\mathbf{5}$ & 0,96 & 0,54 & 1,54 & 0,58 \\
$\mathbf{6}$ & 1,19 & 0,24 & 1,09 & 0,41 \\
$\mathbf{7}$ & 1,13 & 0,13 & 1,33 & 0,24 \\
$\mathbf{8}$ & 1,23 & 0,49 & 1,61 & 0,88 \\
$\mathbf{9}$ & 1,35 & 0,54 & 1,68 & 0,76 \\
$\mathbf{1 0}$ & - & - & - & - \\
$\mathbf{1 1}$ & 1,14 & 0,43 & 1,69 & 0,58 \\
$\mathbf{1 2}$ & 1,75 & 0,30 & 1,89 & 1,12 \\
\hline
\end{tabular}

\subsubsection{Condições gengivais em áreas rurais homogêneas}

\subsubsection{Sangramento gengival à sondagem}

Pode-se observar diversidade entre as classes na prevalência de sangramento gengival à sondagem na dentição decídua. $\mathrm{Na}$ área rural homogênea classificada como número 10, nenhuma criança apresentou o agravo estudado. Entretanto, em 63\% das crianças da classe 2 (áreas rurais de agricultura de subsistência) foram observados sangramento gengival à sondagem. (Tabela 6.4.2.1.1). 
Tabela 6.4.2.1.1 Áreas rurais homogêneas de acordo com a presença de sangramento gengival à sondagem $(\mathrm{CPI}=1)$ na dentição decídua. São Paulo, 1998.

\begin{tabular}{crccc}
\hline & \multicolumn{2}{c}{$\mathbf{C P I}=\mathbf{1}$} & \multicolumn{2}{c}{$\mathbf{C P I}=\mathbf{0}$} \\
\cline { 2 - 5 } Classe & \multicolumn{1}{c}{$\mathbf{N}$} & $\mathbf{\%}$ & $\mathbf{N}$ & $\mathbf{\%}$ \\
\hline $\mathbf{1}$ & 65 & 30,66 & 147 & 69,34 \\
$\mathbf{2}$ & 112 & 63,28 & 65 & 36,72 \\
$\mathbf{3}$ & 11 & 28,95 & 27 & 71,05 \\
$\mathbf{4}$ & 11 & 47,83 & 12 & 52,17 \\
$\mathbf{5}$ & 108 & 52,17 & 99 & 47,83 \\
$\mathbf{6}$ & 115 & 32,76 & 236 & 67,24 \\
$\mathbf{7}$ & 179 & 49,04 & 186 & 50,96 \\
$\mathbf{8}$ & 81 & 61,83 & 50 & 38,17 \\
$\mathbf{9}$ & 143 & 61,90 & 88 & 38,10 \\
$\mathbf{1 0}$ & 0 & 0,00 & 33 & 100,00 \\
$\mathbf{1 1}$ & 64 & 48,12 & 69 & 51,88 \\
$\mathbf{1 2}$ & 23 & 53,49 & 20 & 46,51 \\
\hline
\end{tabular}

Na faixa etária de 10 a 12 anos, também se pode observar diversidade entre as classes na prevalência de sangramento gengival à sondagem. Na área rural homogênea classificada como número 8 (caracterizada pela presença de minifúndios), a maioria dos escolares examinados apresentou condição gengival não sadia $(84,43 \%)$. Entretanto, em $90 \%$ dos escolares da classe 10 não foram observados sangramento gengival à sondagem. (Tabela 6.4.2.2). 
Tabela 6.4.2.1.2 Áreas rurais homogêneas de acordo com a presença de sangramento gengival a sondagem (CPI=1) na dentição permanente. São Paulo, 1998.

\begin{tabular}{ccccc}
\hline & \multicolumn{2}{c}{$\mathbf{C P I} \geq \mathbf{1}$} & \multicolumn{2}{c}{$\mathbf{C P I}=\mathbf{0}$} \\
\cline { 2 - 5 } Classe & $\mathbf{N}$ & $\mathbf{\%}$ & $\mathbf{N}$ & $\mathbf{\%}$ \\
\hline $\mathbf{1}$ & 123 & 38,56 & 196 & 61,44 \\
$\mathbf{2}$ & 118 & 66,67 & 59 & 33,33 \\
$\mathbf{3}$ & 21 & 26,25 & 59 & 73,75 \\
$\mathbf{4}$ & 29 & 50,00 & 29 & 50,00 \\
$\mathbf{5}$ & 150 & 70,82 & 103 & 29,18 \\
$\mathbf{6}$ & 174 & 55,95 & 137 & 44,05 \\
$\mathbf{7}$ & 95 & 86,36 & 15 & 13,64 \\
$\mathbf{8}$ & 206 & 84,43 & 38 & 15,57 \\
$\mathbf{9}$ & 206 & 84,43 & 38 & 15,57 \\
$\mathbf{1 0}$ & 3 & 10,00 & 27 & 90,00 \\
$\mathbf{1 1}$ & 99 & 63,29 & 44 & 36,41 \\
$\mathbf{1 2}$ & 22 & 59,46 & 15 & 40,54 \\
\hline
\end{tabular}

\subsubsection{Cálculo dental em áreas rurais homogêneas}

$\mathrm{Na}$ faixa etária de 5 a 7 anos, foram encontrados cálculo dental visível em $12 \%$ das crianças pertencentes a áreas rurais com características socioeconômicas classificadas como classe 6 (áreas com restrições naturais para a exploração das terras). Nenhuma criança das classes 3, 4 e 10 apresentou essa condição (Tabela 6.4.2.2.1) 
Tabela 6.4.2.2.1. Áreas rurais homogêneas de acordo com a presença de cálculo dental visível (CPI=2) na dentição decídua. São Paulo, 1998.

\begin{tabular}{ccccc}
\hline & \multicolumn{2}{c}{$\mathbf{C P I}=\mathbf{2}$} & \multicolumn{2}{c}{$\mathbf{C P I} \leq \mathbf{1}$} \\
\cline { 2 - 5 } Classe & $\mathbf{N}$ & $\mathbf{\%}$ & $\mathbf{N}$ & $\mathbf{\%}$ \\
\hline $\mathbf{1}$ & 3 & 1,42 & 209 & 98,58 \\
$\mathbf{2}$ & 14 & 7,91 & 163 & 92,09 \\
$\mathbf{3}$ & 0 & 0,00 & 38 & 100,00 \\
$\mathbf{4}$ & 0 & 0,00 & 23 & 100,00 \\
$\mathbf{5}$ & 11 & 5,61 & 196 & 94,39 \\
$\mathbf{6}$ & 41 & 11,68 & 310 & 88,32 \\
$\mathbf{7}$ & 27 & 7,40 & 338 & 92,60 \\
$\mathbf{8}$ & 8 & 6,10 & 123 & 93,90 \\
$\mathbf{9}$ & 11 & 8,40 & 220 & 91,60 \\
$\mathbf{1 0}$ & 0 & 0,00 & 33 & 100,00 \\
$\mathbf{1 1}$ & 9 & 6,77 & 124 & 93,23 \\
$\mathbf{1 2}$ & 1 & 2,33 & 42 & 97,97 \\
\hline
\end{tabular}

$\mathrm{Na}$ faixa etária de 10 a 12 anos, 38,26\% dos escolares da classe 6 apresentaram cálculo dental visível. Na classe 3 (médias a grandes propriedades de terra), no entanto, 98,75\% dos escolares apresentaram condição gengival sadia ou presença de sangramento à sondagem mas sem a presença de cálculo visível (Tabela 6.4.2.2.2) 
Tabela 6.4.2.2.2 Áreas rurais homogêneas de acordo com a presença de cálculo dental visível (CPI=2) na dentição permanente. São Paulo, 1998.

\begin{tabular}{ccccc}
\hline & \multicolumn{2}{c}{$\mathbf{C P I}=\mathbf{2}$} & \multicolumn{2}{c}{$\mathbf{C P I} \leq \mathbf{1}$} \\
\cline { 2 - 5 } Classe & $\mathbf{N}$ & $\mathbf{\%}$ & $\mathbf{N}$ & $\mathbf{\%}$ \\
\hline $\mathbf{1}$ & 12 & 3,76 & 307 & 96,24 \\
$\mathbf{2}$ & 53 & 29,94 & 124 & 70,06 \\
$\mathbf{3}$ & 1 & 1,25 & 79 & 98,75 \\
$\mathbf{4}$ & 14 & 24,13 & 44 & 75,87 \\
$\mathbf{5}$ & 86 & 24,36 & 267 & 75,64 \\
$\mathbf{6}$ & 119 & 38,26 & 192 & 61,74 \\
$\mathbf{7}$ & 132 & 29,20 & 320 & 70,80 \\
$\mathbf{8}$ & 34 & 30,91 & 76 & 69,09 \\
$\mathbf{9}$ & 59 & 24,18 & 185 & 75,82 \\
$\mathbf{1 0}$ & 2 & 6,67 & 28 & 93,33 \\
$\mathbf{1 1}$ & 29 & 20,28 & 114 & 79,72 \\
$\mathbf{1 2}$ & 6 & 16,22 & 31 & 83,78 \\
\hline
\end{tabular}




\section{DISCUSSÃO}

Neste estudo, foram analisados dados secundários de cárie dentária e condições gengivais, provenientes originalmente do banco de dados gerado pelo Levantamento Epidemiológico de Saúde Bucal: Estado de São Paulo, 1998 (USP 1999). De acordo com o relatório final desse levantamento (USP 1999), as informações obtidas permitem estratificar a amostra segundo localidade aonde se encontra a escola (urbana ou rural). No entanto, o delineamento da amostra não foi programado para garantir inferência probabilística de resultados relativos a essa estratificação. Além disso, a classificação dos escolares como sendo de área urbana ou rural refere-se à localização da escola que freqüentavam e, nesse sentido, essa informação não reflete obrigatoriamente a área de residência. Também não podem ser inferidas informações para as áreas rurais que não participaram do levantamento. Apesar dessas limitações, o elevado número de indivíduos examinados, combinado com a dispersão dos pontos de coleta dos dados, tanto no Estado como em cada cidade, encorajou os autores a explorar as diferenças na experiência de cárie e condições gengivais, e sua associação com indicadores de desenvolvimento social em áreas urbanas e rurais do Estado.

Este foi o maior levantamento epidemiológico de saúde bucal realizado no Estado de São Paulo, mobilizou muitas pessoas, dentre os profissionais e os participantes da pesquisa, e demandou um esforço relevante de toda a sociedade. 
Nesse sentido, o presente estudo assumiu como importante a análise exploratória de seus resultados, valorizando o esforço despendido em sua realização, e contribuindo para implementar o planejamento de políticas de promoção e recuperação da saúde bucal em nosso meio. Além disso, considerou-se a escassez de trabalhos avaliando as condições de saúde bucal de populações residentes em áreas rurais brasileiras.

Optou-se por focalizar a descrição e análise da distribuição de cárie dentária e de condições gengivais em dois grupos etários (5 a 7 anos e 10 a 12 anos), com o intuito de ampliar a amostra de escolares matriculados em áreas rurais. A distribuição por idade nos dois grupos etários não é homogênea nos escolares de área urbana e rural, o que pode ter contribuído para justificar, em parte, as discrepâncias relatadas nos indicadores de cárie e condições gengivais (Tabela 6.1.1 e Tabela 6.1.2). Na faixa etária de 5 a 7 anos, $53 \%$ da amostra da área rural é composta por crianças de 7 anos, uma proporção mais elevada que a observada para a área urbana. Assim, os indicadores de necessidade de tratamento odontológico, obtido através da prevalência de cárie não tratada, nessa faixa etária, podem estar superestimadas em áreas rurais, em função de características instrínsecas à forma como a medida foi efetuada. Por exemplo, alguns dentes decíduos cariados, aos 7 anos, estão prestes a serem esfoliados e, apesar de serem considerados cariados, não deveriam implicar necessidade de tratamento. A média do índice ceo-d, entretanto, pode estar subestimada na área rural por razões análogas, sendo possível que alguns dentes decíduos cariados já tenham esfoliado aos 7 anos (Tabela 6.1.1.). Para a análise das necessidades de tratamento odontológico na dentição permanente, os indicadores observados nas áreas rurais podem estar subestimados, pois $44 \%$ dos escolares têm 
10 anos e, nessa idade, alguns ainda apresentam um número reduzido de dentes permanentes já irrompidos, e sabe-se que o risco de desenvolver cárie dentária aumenta com a idade (Tabela 6.1.2). Os indicadores de alterações gengivais também podem sofrer a influência desse fator. $\mathrm{O}$ índice de sangramento gengival e presença de cálculo na faixa etária de 5 a 7 anos na área rural pode estar superestimado e na faixa etária de 10 a 12 anos, pode estar subestimado na área rural. Pois, o risco de desenvolver essas condições aumenta com a idade (PETERSEN e MZEE 1998).

As médias dos índices ceo-d $(4,64)$ e CPO-D $(3,25)$ observadas para a área rural do Estado podem ser classificadas, respectivamente, como níveis alto e moderado de prevalência, de acordo com a escala usada por PETERSEN (2003) (Tabelas 6.2.1 e Tabela 6.2.2). Níveis semelhantes foram observados nas áreas rurais de Itapetininga, município do Estado de São Paulo (MELLO e ANTUNES 2004), em Itaúna, Minas Gerais (ABREU et al. 2004) e em localidades rurais africanas (ATTIN et al. 1999; BRINDLE et al. 2000). Em outras áreas rurais brasileiras, HILLI (1976) em Londrina, MARQUES et al. (1986) em Uberlândia e DINI et al. (1993) em Araraquara observaram prevalência de cárie na dentição permanente ainda mais elevada que a encontrada neste estudo. Em algumas comunidades rurais africanas e asiáticas, porém, foram observados indicadores mais favoráveis de saúde bucal (SATHANANTHAN et al. 1996; JAMEL et al. 1997; MILSOM et al. 1997; PETERSEN e MZEE 1998; NALWEYISO et al. 2004). Entretanto, nesses casos, os baixos índices foram atribuídos às características de isolamento das áreas rurais desses países, e à condição de intensa privação social dessas populações.

Nas duas faixas etárias estudadas, maior proporção de crianças livres de cárie, menor percentual com elevada prevalência da doença, menores valores para o 
componente cariado do índice CPO-D e ceo-d e maiores índices de cuidado (IC) foram observados nas crianças residentes em áreas urbanas (Tabela 6.2.1 e Tabela 6.2.2), indicando que os escolares de áreas rurais do Estado (em relação aos da área urbana) possuem piores condições de saúde bucal. Esse resultado reflete o que foi encontrado no município de Itapetininga (MELLO e ANTUNES 2004). Situação oposta, entretanto, foi observada em estudos realizados em áreas rurais consideradas isoladas e mantenedoras de hábitos alimentares tradicionais: na África (MOALIC et al, 1998; PETERSEN e MZEE 1998; BLAY al. 2000); Iraque (JAMEL et al. 1997); América Central (ALONGE e NAREDRAN, 1999) e Austrália (BRENNAN et al. 2000). Essas indicações sugerem que o maior isolamento dos grupos residentes em áreas rurais, sua distância em relação aos centros urbanos, o menor acesso a produtos industrializados açucarados, podem ter contribuído para o registro de menor prevalência de cárie. Consistente com essa hipótese, DINI et al. (1993); JAMEL et al. (1997); BLAY et al. (2000); IRIGOYEN et al. (2000) e SAMPAIO et al. (2000) observaram que os moradores de áreas rurais apresentavam baixo consumo de açúcar. De acordo com MELLO e ANTUNES (2004), esse baixo consumo talvez possa ser atribuído ao fato de que elevada porcentagem das famílias rurais brasileiras vive com um salário mínimo ou menos. Para SAMPAIO et al. (2000), no entanto, a dieta está mudando nas áreas rurais do Brasil, em função do maior acesso aos produtos industrializados e ao açúcar, o que pode provocar um aumento na prevalência de cárie dentária dessas populações.

A maior dificuldade de acesso a serviços de saúde bucal dos residentes em áreas rurais foi relatada em diversos estudos de áreas rurais de diferentes países (HILLE 1976; CANTON et al. 1985; MARQUES et al. 1986; MANJI et al. 1988; 
DINI et al. 1993; BRENNAN et al. 2000; SATHANANTHAN et al. 1996; NTABAYE et al. 1998; ALONGE e NAREDRAN 1999; ATTIN et al. 1999; BRINDLE et al. 2000; CROWLEY et al. 2000; IRIGOYEN et al. 2000; MATTILA et al. 2000; TEIXEIRA et al. 2000; MELLO e ANTUNES 2004). Para as crianças de 5 a 7 anos, tanto em áreas urbanas como rurais existe uma baixa incorporação dos serviços odontológicos para a dentição decídua.. Porém, a situação é ainda mais preocupante nas áreas rurais do Estado, visto que o componente c (cariado) é responsável por $75 \%$ do valor do índice ceo-d (Tabela 6.2.1). Situação semelhante foi verificada por SATHANANTHAN et al. (1996) BRINDLE et al. (2000) e MELLO e ANTUNES (2004), com as crianças de cinco anos, nesses estudos, apresentado prevalência de cárie não tratada significativamente mais elevada que as crianças de 12 anos. Esta informação é consistente com pesquisa sobre acesso e utilização de serviços de saúde no Brasil realizada em 2003, que apontou um reduzido percentual $(18,1 \%)$ das crianças com menos de cinco anos de idade que já consultaram o dentista ao menos uma vez na vida (BRASIL 2005).

A baixa incorporação de tratamento odontológico restaurador nas crianças de cinco anos de idade também pode refletir a falta de conhecimento dos pais sobre a importância da dentição decídua. BRINDLE et al. (2000) constataram que os pais, moradores em áreas rurais, nunca haviam informado os filhos quanto à importância de se visitar o cirurgião-dentista, pois, naquela comunidade carente da África, haviase priorizado o enfrentamento de outras condições, como a situação social de extrema miséria e a elevada prevalência de desnutrição infantil. Esse fator também pode ter contribuído para a priorização do atendimento odontológico de crianças em idade escolar nos programas de saúde bucal em área rural promovidos no passado 
pelo serviço público no Brasil, como foi observado por MELLO e ANTUNES (2004) na área rural de Itapetininga, São Paulo.

Além de documentar os níveis atuais da necessidade de tratamento odontológico em áreas urbana e rural do Estado, o presente estudo avaliou também a desigualdade em sua distribuição entre crianças com diferentes características sóciodemográficas. A influência dessas variáveis na experiência de cárie e necessidade de tratamento odontológico tem sido analisada por diversos autores nacionais e internacionais (SCHOU e UITENBROEK 1995; PERES et al. 2000; ANTUNES et al. 2002; BALDANI et al. 2002; WATT 2005).

Utilizando o indivíduo como unidade de análise (Tabela 6.2.3 e Tabela 6.2.4), observou-se menor prevalência de cavidade de cárie não tratada para meninas do que para meninos. No contexto brasileiro, esse resultado pode ser indicativo de uma valorização diferencial das dimensões estética e funcional da saúde bucal de meninas e meninos, por parte dos pais e da sociedade o que poderia facilitar o acesso a tratamento odontológico para as meninas (ANTUNES et al. 2006). Porém, essa não é uma indicação de melhores condições de saúde bucal. A menor prevalência de cárie não tratada nas meninas indica melhor acesso a tratamento, mas deve ser ponderada por diferenças na cronologia de erupção dos dentes permanentes, uma vez que a erupção precoce nas meninas, em relação aos meninos de mesma idade, determina risco mais elevado de cárie em dentes permanentes (ANTUNES et al. 2003). Para a faixa etária de dentição decídua, em áreas rurais do Estado, não houve diferença de gênero para a prevalência de cárie não tratada, em observação semelhante à efetuada por ABREU et al. (2004) na área rural de Itaúna, MG. Apesar da ausência de disparidade entre os gêneros para essa condição, reitera-se que isso foi verificado em 
um contexto de baixo acesso a tratamento odontológico tanto para meninos como para meninas de áreas rurais do Estado (Tabela 6.2.3 e Tabela 6.2.4).

Também se observou acesso desigual a tratamento odontológico na comparação entre crianças brancas e crianças negras ou pardas (Tabela 6.2.3 e Tabela 6.2..4). Esta observação representa uma indicação adicional de desigualdade sócio-demográfica afetando a experiência de cárie. Estudos anteriores sobre o tema atribuem essas diferenças exclusivamente à discrepante inserção socioeconômica desses segmentos de população e ao acesso diferencial a bens e serviços no Brasil, descartando possíveis fundamentos biológicos (ANTUNES et al. 2002; ANTUNES et al. 2003). Na área rural do Estado, para a dentição permanente, não foi encontrada diferença entre os grupos étnicos. Entretanto, a porcentagem de escolares com ao menos um dente cariado não tratado foi elevada tanto no grupo de brancos como no de negros e pardos (Tabela 6.2.4).

Na faixa etária de 5 a 7 anos, tanto em áreas urbanas como rurais do Estado, os estudantes de escolas públicas apresentaram maior prevalência de cárie não tratada em relação aos estudantes de escolas particulares (Tabela 6.2.3). O tipo de escola, pública ou privada, é utilizado como indicador de condições socioeconômicas. Como as escolas públicas não cobram taxas escolares, crianças de escolas privadas têm sido consideradas como sendo de condição socioeconômica mais favorável. No contexto brasileiro, estudantes de escolas públicas têm mais chance de ter pais com níveis de instrução mais baixos e menor renda per capita que os estudantes de escolas particulares (MALTZ e SILVA 2001). Em países da Europa, NADANOVSKY e SHEIHAM (1995) observaram que o nível de educação das mães foi melhor preditor de experiência de cárie que o acesso a serviços de saúde bucal. 
Pessoas com maior grau de educação formal tendem a escovar seus dentes mais vezes e seus filhos aderem mais facilmente a hábitos bucais saudáveis (BALDANI et al. 2002).

De acordo com EL-NADEEF et al. (1998), quando as características socioeconômicas são controladas, as diferenças na prevalência de cárie entre as áreas urbana e rural desaparecem. No entanto, a análise de regressão logística multivariada (Tabela 6.2.5 e Tabela 6.2.6) indicou que todas as variáveis sócio-demográficas descritas anteriormente se mantiveram estatisticamente associadas com a prevalência de cárie não tratada em ambas as faixas etárias estudadas. Ser negro ou pardo, estudar na área rural e em escola pública foram identificados como determinantes individuais de chance mais elevada de apresentar cavidade de cárie não tratada. Ser do sexo feminino foi identificado como fator de proteção para essa condição.

O modelo multinível explicativo da necessidade de tratamento odontológico permitiu indicar o Índice de Desenvolvimento Humano Municipal (IDH-M) e o acesso à água fluoretada como sendo condições contextuais significativamente associadas à necessidade de tratamento odontológico, após ajuste para as características sócio-demográficas dos escolares examinados (Tabela 6.2.5 e Tabela 6.2.6).

O IDH-M mede o desenvolvimento humano a partir de indicadores de educação, longevidade e renda. As tabelas 6.2 .5 e 6.2.6 indicam uma correlação negativa entre a prevalência de cárie não tratada e Índice de Desenvolvimento Humano Municipal (IDH-M). A associação contextual entre condições de saúde e condições socioeconômicas está bem estabelecida na literatura mundial. Em geral, quanto piores as condições socioeconômicas, piores os indicadores de saúde, 
inclusive os relativos à cárie dentária (PERES et al. 2005). Na faixa etária de 5 a 7 anos, além do Índice de Desenvolvimento Humano Municipal (IDH-M), a adição de flúor no sistema de abastecimento de água teve correlação negativa com a prevalência de cárie não tratada (Tabela 6.2.5). Estudos no contexto internacional têm indicado que esse recurso, além de contribuir para a redução de prevalência da cárie, seria efetivo para a redução da desigualdade em sua distribuição (JONES et al. 1997, BURT 2002).

Não obstante, esta consideração é limitada para o contexto brasileiro, em função de intensos contrastes na implementação da medida. Muitos municípios não efetuam a adição de flúor à água de abastecimento público, e muitos dos que o fazem apresentam ponderável proporção de domicílios não ligados à rede de águas. Esta observação sugere que a água fluoretada não vem beneficiando a população de modo homogêneo (PERES et al.2004), e que há espaço para uma ainda mais intensa redução dos indicadores epidemiológicos da cárie no país, através da implementação desse recurso para as cidades que ainda não o oferecem, e através da ampliação de cobertura do sistema de abastecimento de água para as cidades que já disponibilizam o benefício. Em áreas rurais brasileiras e internacionais, o benefício do flúor na água pode ser recebido pela minoria das pessoas. Em Itaúna (MG), apenas 28,3\% das famílias de áreas rurais utilizavam a água tratada fornecida pelo Sistema de Abastecimento de Água e Esgoto (SAAE) local (ABREU et al. 2004). Como, em sua maior parte, os domicílios localizados em áreas rurais não estão conectados ao sistema de abastecimento de água, através do qual o flúor é veiculado. E em áreas rurais que apresentem concentração natural desse íon na água, encontra-se menores valores do índice CPO-D. (SAMPAIO et al. 2000). 
No Brasil, o flúor tópico pode ser recebido pela população urbana e rural através dos dentifrícios fluoretados, largamente utilizados desde o final da década de 1980. Entretanto, residentes em áreas rurais apresentaram-se menos propensos a desenvolverem ações preventivas de saúde bucal, como a escovação correta dos dentes, que os residentes em áreas urbanas correspondentes (BLAY et al. 2000). Semelhante à situação notada em Araraquara por DINI et al. (1993), na área rural de Itapetininga, MELLO e ANTUNES (2004) observaram que, ainda que a maioria dos responsáveis tivesse respondido que seus filhos escovavam os dentes 2 ou 3 vezes por dia, o exame bucal realizado permitiu constatar serem precárias as condições de higiene oral, sugerindo que essa resposta poderia não ser confiável. Essa observação poderia também estar refletindo deficiências no processo de escovação efetuado pelas crianças, pois $61 \%$ dos responsáveis pelas crianças de cinco anos da área rural de Itapetininga responderam que elas escovavam sozinhas os seus dentes, sem apoio ou supervisão dos adultos. Na Nigéria, foi relatado que apenas $10 \%$ das crianças de áreas rurais usavam escova e dentifrício para realizar a higiene dos dentes (SOFOLA et al. 2003). Sabendo-se que a não realização adequada da escovação dentária permite o acúmulo de placa bacteriana e que essa condição permite o desenvolvimento de placa bacteriana com potencial cariogênico e periodontopatogênico; isto é, capazes de causar os primeiros indícios de dissolução no esmalte e alterações aos tecidos periodontais (THYLSTRUP 2001), esse fator pode ser identificado como um dos responsáveis pelos elevados valores dos indicadores tanto de cárie como de condições gengivais encontrados em áreas rurais do Estado (Tabelas 6.2.1 e 6.2.2, Gráficos 6.3.1.1 e 6.3.1.2). 
Apresentaram sangramento gengival à sondagem uma elevada porcentagem dos escolares das áreas rurais do Estado nas duas faixas etárias estudadas (46\% na faixa etária de 5 a 7 anos e $65 \%$ de 10 a 12 anos) (Tabelas 6.3.1.1 e 6.3.1.2). Apesar disso, essas porcentagens indicam melhores condições gengivais em áreas rurais do Estado de São Paulo que as observadas em áreas rurais Africanas. Segundo BRINDLE et al. (2000) essa condição reflete o baixo valor atribuído pelos habitantes de áreas com intensa privação social no continente africano à necessidade de desenvolvimento de hábitos bucais saudáveis. Entretanto, na área rural de Itatiba, estado de São Paulo, CANGUSSU et al. (2001) encontraram melhores condições gengivais em crianças de 5 anos e adolescentes de 12 e 15 anos, pois houve predomínio de sextantes sadios naquela comunidade. Segundo os autores, um dos elementos que poderia estar contribuindo para esse resultado foi o investimento em programas educativos e preventivos, com distribuição de escovas e reforço continuado nas técnicas de escovação e educação em saúde bucal que está sendo realizado no município, inclusive nas áreas rurais. Outro fator que poderia explicar essa diferença é que os indicadores de condições gengivais analisados neste estudo foram obtidos através de faixas etárias e, por exemplo, a incorporação de escolares de 7 anos na análise de sangramento gengival na dentição decídua pode superestimar o índice.

Fatores socioeconômicos, comportamentais e demográficos que podem influenciar a prevalência e severidade da cárie dentária também influenciam a prevalência e severidade das doenças gengivais. Os escolares de áreas rurais apresentaram prevalência mais elevada de sangramento gengival à sondagem e cálculo visível em relação aos escolares de áreas urbanas do Estado (Tabelas 6.3.1.1, 
6.3.1.2, 6.3.2.1 e 6.3.2.2), situação semelhante à encontrada na Nigéria (SOFOLA et al. 2003). Em comunidades africanas, onde a maioria das crianças apresenta gengiva não saudável, não foi encontrada diferença entre áreas urbana e rural (MUMGHAMBA et al. 1996; PETERSEN e MZEE 1998).

As meninas apresentaram melhores indicadores de condições gengivais que os meninos no Estado de São Paulo, tanto em áreas urbanas como rurais, apesar dessa associação não ser significativa para a dentição decídua na área urbana e para a dentição permanente na área rural (Tabelas 6.3.1.1 e 6.3.1.2). Muitos estudos relatam que as meninas tendem a desenvolver ações de promoção da saúde bucal mais frequentemente que os meninos (KUUSELA et al. 1997; ASTROM et al. 1998). Em áreas rurais africanas, a maioria dos estudos relata que as mulheres escovam mais os dentes que os homens (MUMGHAMBA et al. 1996).

Também foram observadas piores condições gengivais em escolares negros e pardos, em relação aos brancos nas duas áreas estudadas, e provenientes de escolas públicas, em relação aos de escolas privadas na área urbana (Tabelas 6.3.1.1 e 6.3.1.2). Os diferenciais socioeconômicos envolvidos na comparação desses dois grupos podem ser indicados como fatores explicativos para a disparidade dos indicadores de cárie e de condições gengivais relatadas. Crianças de estratos socioeconômicos menos favorecidos apresentam significativamente pior higiene oral e maior prevalência de sangramento gengival e cálculo dentário (SOFOLA et al. 2003).

O Índice de Cuidados Odontológicos (IC) apareceu no modelo multinível como indicativo contextual negativamente associado com a prevalência de sangramento gengival (Tabelas 6.3.1.3 e 6.3.1.4) e cálculo (Tabelas 6.3.2.3 e 6.3.2.4) 
após ajuste para as características sócio-demográficas dos escolares examinados. Esse índice mede a porcentagem de dentes restaurados em relação ao total de dentes decíduos ou permanentes com história de ataque de cárie (índices ceo-d e CPO-D), e corresponde à proporção da necessidade de tratamento odontológico que já pôde ser atendida. Assim, a correlação negativa encontrada indica que quanto maior o acesso a tratamento odontológico na comunidade, menor a prevalência de sangramento gengival e cálculo dentário. O sangramento gengival indica sinais de presença de inflamação local, a qual pode regredir por meio da implementação de hábitos regulares e efetivos de escovação dentária. A presença de cálculo dentário não implica necessariamente comprometimento dos tecidos periodontais, mas sua remoção demanda o atendimento odontológico para a aplicação de procedimentos de raspagem e alisamento coronário e radicular (BASSANI e LUNARDELLI 2006).

A desigualdade em saúde bucal é um fato que chama a atenção no cenário brasileiro. As diferenças estão presentes não apenas nas grandes regiões do país (ANTUNES et al. 2006b), mas também entre as regiões de um Estado (BALDANI et al. 2002), e até mesmo nos diferentes bairros de um município (ANTUNES 2002). As diversas regiões rurais do Estado de São Paulo possuem características históricas, sociais, econômicas e culturais distintas, interferindo no perfil de saúde de suas populações, prevalecendo piores indicadores para os grupos com pior qualidade de vida. A heterogeneidade das áreas rurais brasileiras inicia-se na definição do que é considerado urbano e o que é considerado rural. De acordo com o Instituto Brasileiro de Geografia e Estatística (IBGE), área urbana é definida como a área interna ao perímetro urbano de uma cidade ou vila definida por lei municipal. Área rural é definida como a porção de um município que é externa ao perímetro urbano. Sendo 
assim, as definições de áreas urbanas e rurais são diretamente influenciadas por resoluções de cada município. As discussões mais recentes sobre o meio rural brasileiro revelam características heterogêneas em relação, por exemplo, à inserção no processo de produção e à renda de moradores de diferentes áreas rurais (SILVA et al. 2002). Para tentar relacionar as características desiguais socioeconômicas do meio rural paulista e suas condições de saúde bucal, utilizou-se a classificação de CHABARIBERY (1999). Através de métodos de análise multivariada, utilizando os municípios como unidade de observação e os indicadores econômicos e sociais, a autora desenvolveu uma tipologia da área rural do Estado de São Paulo, combinando indicadores da produção, tecnologia, pessoal ocupado, patrimônio agrícola, incidência de pobreza e de bem-estar social. Os métodos estatísticos permitiram agrupar as áreas rurais com algum grau de homogeneização nas variáveis consideradas, sendo encontradas classes que mostram distintos graus de desenvolvimento agrícola e de bem-estar. Essa é a única divisão do meio rural do Estado disponível na literatura, e considera não apenas diferenças geográficas, mas também econômicas e sociais.

Dentre as áreas rurais do Estado, a que foi classificada como 10 apresentou os melhores indicadores de saúde bucal, tanto para cárie dentária como para condições gengivais (Tabelas 6.4.1.1 à 6.4.2.2.2). Essa classe é composta pela região de Ribeirão Preto, atualmente é um dos principais pólos agroindustriais paulista, a qual tem assistido a implementação da agricultura desde o final do século XIX, quando se propiciou a expansão da cafeicultura. Os municípios integrados a essa classe apresentam intenso dinamismo econômico, com alta taxa de crescimento da população (3,3\% ao ano), taxa de urbanização de $88,1 \%$ e alta densidade 
demográfica $\left(262,5 \mathrm{hab} / \mathrm{km}^{2}\right)$. Trata-se de região com agricultura patronal e familiar em grandes propriedades de terra, alta modernização agrícola e muito elevada integração às instituições financeiras. Dentre as classes rurais, é a que apresenta o mais elevado índice de condição de vida $(0,80)$, e o fato de ter também apresentado os indicadores mais favoráveis de saúde bucal reforça a estreita relação entre condições socioeconômicas e níveis de saúde bucal.

As áreas rurais classificadas como pertencentes à classe 12 apresentaram elevada prevalência de cárie dentária tanto na dentição decídua como na permanente (Tabela 6.4.1.1 e 6.4.1.2). Essa região é composta por propriedades de tamanhos médios a grandes, com 85 ha de área média, e valor da produção por estabelecimento acima da média do Estado. Seu sistema de produção caracteriza-se pela associação das lavouras de laranja, cana, milho, frutas e algodão, ou pela associação entre milho, soja, trigo e cana. A facilidade de acesso ao açúcar nas áreas rurais que cultivam a cana pode contribuir para explicar a elevada prevalência de cárie encontrada nessa classe 12. Entretanto, SAMPAIO et al. (2000) observaram que, apesar das crianças residentes em áreas rurais de cultivo da cana relatarem o consumo freqüente de rapadura (doce típico de regiões brasileiras produzido com a cana-de-açúcar), essa era consumida com menor freqüência que o açúcar processado industrialmente, possivelmente em função de seu mais fácil acesso e menor custo. Na classe 12, a proporção de dentes já tratados medida pelo índice de cuidado (IC) revelou-se baixa para as crianças de 5 a 7 anos, porém foi elevada para os escolares de 10 a 12 anos. Deve-se levar em consideração que os indicadores socioeconômicos das áreas rurais que compõem essa classe apontam um rápido progresso; e seu índice de condição de vida encontra-se no limite entre os valores considerados médio e alto. 
$\mathrm{Na}$ classe 2, 63\% das crianças de 5 a 7 anos apresentaram sangramento gengival à sondagem (Tabela 6.4.2.1.1), a porcentagem mais elevada para esse indicador, dentre as regiões rurais homogêneas do Estado. Essa região congrega municípios que apresentam baixa urbanização e baixo índice de condição de vida. $\mathrm{O}$ corredor formado entre o município de Capão Bonito a Itararé, chamado de "ramal da fome", faz parte dessa classe. Na faixa etária de 10 a 12 anos, $81 \%$ dos escolares da classe 7 apresentaram sangramento gengival (Tabela 6.4.2.1.2) e valores muito baixos do índice de cuidado $(\mathrm{IC}=20 \%)$ (Tabela 6.4.1.2) indicando falta de acesso à tratamento odontológico. Trata-se de classe de agricultura familiar de baixa renda em regiões de condições naturais restritas.

Apresentaram cálculo dental visível, 41 crianças de 5 a 7 anos (12\%) (Tabela 6.4.2.2.1) e 119 escolares de 10 a 12 anos (38\%) (Tabela 6.4.2.2.2) da classe 6. Essa classe abrange áreas com restrições rurais naturais, com produção agropecuária de baixo valor e baixo índice de condições de vida. Sabendo que a remoção do cálculo dental, sempre que for necessária, precisa ser realizada no consultório odontológico, entende-se que as crianças das áreas rurais que compõem essa classe necessitam de políticas públicas que possibilitem o acesso a esse tratamento.

As diferenças na distribuição dos agravos à saúde bucal em indivíduos e populações com características sociais, econômicas e demográficas distintas encontradas neste estudo são consistentes com achados das literaturas nacionais e internacionais. Porém, são escassos os estudos estimando a prevalência das principais doenças bucais em populações rurais, o que dificulta o planejamento das intervenções em saúde bucal. A inexistência de informação anterior sobre essa 
condição na população rural do Estado impede a avaliação de tendências na distribuição dos agravos.

O presente estudo apresenta informações epidemiológicas inéditas para as áreas rurais do Estado, oferecendo subsídios para o planejamento estratégico e normativo das ações de saúde bucal nos sistemas locais de saúde, com o intuito de contribuir para a promoção de eqüidade em saúde. O monitoramento contínuo da experiência de cárie no país pode instruir o direcionamento de recursos adicionais para as áreas com maiores necessidades; contribuindo, desse modo, para a implementação de um serviço de saúde socialmente apropriado. 


\section{CONCLUSÕES}

Os escolares da área rural do Estado apresentaram maior prevalência de cárie, sangramento gengival e cálculo dental, além de menor incorporação de serviços odontológicos que os escolares residentes na área urbana, mostrando-se mais vulneráveis para todas as condições de saúde bucal avaliadas.

Estudar em áreas rurais, em escolas públicas, ser negro ou pardo e ser do sexo masculino foram fatores associados com a manifestação de cárie não tratada, presença de sangramento gengival à sondagem e cálculo dental, no nível do indivíduo. A presença de flúor na água de abastecimento público e o IDH-M associaram com essas condições ao nível das cidades participantes do levantamento

Áreas rurais de municípios com melhores indicadores de condições de vida e cujo sistema produtivo apresenta maior implementação da economia agroindustrial tiveram os melhores indicadores de saúde bucal. Nas áreas rurais do Estado que apresentam piores indicadores de privação socioeconômica as medidas de saúde bucal também apontaram situações desfavoráveis. 


\section{REFERÊNCIAS}

Abreu MHNG, Pordeus IA, Modena CM. Cárie dentária entre escolares do meio rural de Itaúna (MG), Brasil. Rev Panam Salud Publica/Pan Am J Public Health 2004; 16(50: 334-343.

Albuquerque RHPL. Capital comercial, indústria têxtil e produção agrícola. São Paulo: Hucitec/Cnpq; 1982.

Alonge OK, Naredran S. Dental caries experience among school children in St. Vincent and The Grenadines: report of the first national oral health survey. Community Dent Health 1999; 16: 45-9.

Antunes JLF. Grow and multiply': social development, birth rates and demographic transition in the Municipality of São Paulo, Brazil, time-series for 1900-94. Rev Bras Epidemiol 1998; 1: 61-78.

Antunes JLF, Frazão P, Narvai PC, Bispo CM, Pegoretti T. Spatial analysis to identify differentials in dental needs by area-based measures. Community Dent Oral Epidemiol 2002; 30: 133-42. 
Antunes JLF, Pegoretti T, Andrade FP, Junqueira SR, Frazão P, Narvai PC. Ethnic disparities in the prevalence of dental caries and restorative dental treatment in Brazilian children. Int Dent J 2003; 53:7-12.

Antunes JLF, Peres MA, Mello TRC. Determinantes individuais e contextuais da necessidade de tratamento odontológico na dentição decídua no Brasil. Ciência $\boldsymbol{\&}$ Saúde Coletiva 2006; 11(1):79-87.

Antunes JLF, Peres MA, Mello TRC, Waldman EA. Multilevel assessment of determinants of dental caries experience in Brazil. Community Dent Oral Epidemiol 2006; 34: 146-52.

Astrom AN, Jakobsen R. Stability of dental health behavior: A 3-year prospective cohort study of 15-, 16-, and 18-year-old Norwegian adolescents. Community Dent Oral Epidemiol 1998; 26:129-38.

Attin T, Mbiydzemo FN, Villard I, Kielbassa AM, Hellwig E. Dental status of schoolchildren from a rural community in C5ameroon. South Afr Dental J 1999; 54: $145-8$.

Baldani MH, Narvai PC, Antunes JLF. Cárie dentária e condições sócio-econômicas no Estado do Paraná, Brasil, 1996. Cad Saúde Pública 2002; 18(3): 755-763. 
Bassani D, Lunardelli AN. Condições periodontais. In: Antunes JLF, Peres MA, editores. Epidemiologia da Saúde Bucal. Rio de Janeiro: Guanabara; 2006, p.68-82.

Blay D, Astrom NA, Haugejorden O. Oral hygiene and sugar consumption among urban and rural adolescents in Ghana. Community Dent Oral Epidemiol 2000; 28: 443-50.

Bönecker M, Cleaton Jones P. Trends in dental caries in Latin American and Caribbean 5-6 and 11-13 year-old children: a systematic review. Community Dent Oral Epidemiol 2003; 31: 152-7.

Botazzo C. Unidade básica de saúde: a porta do sistema revisitada. São Paulo: EDUSC; 1999.

[Brasil]. Ministério do Planejamento, Orçamento e Gestão. Instituto Brasileiro de Geografia e Estatística. Coordenação de Trabalho e Rendimento. Pesquisa nacional por amostra de domicílios 2003: acesso e utilização de serviços de saúde. Rio de Janeiro: IBGE; 2005.

Brennan DS, Spencer AJ, Slade GD. Caries experience among publicly-funded dental patients in Australia, 1995-96: Type of care and geographic location. Aust Dent J 2000; 45: 37-45. 
Brindle R, Wilkinson D, Harrison A, Connoly C, Cleaton-Jones P. Oral heath in Hlabisa, KwaZulu / Natal: a rural school and community based survey. Int Dent J 2000; 50: 13-20.

Brown LJ, Loë H. Prevalence, extent, severity and progression of periodontal disease. Periodontol 2000; 2:57-71.

Burt BA. Fluoridation and social equity. J PublicHealth Dent 2002; 62:195-200.

Cangussu MCT, Coelho EO, Castellanos RAF. Rev FOB 2001; 9(1/2):77-85.

Canton L, Doño R, Bellagamba S, Schmunis S. Atención primária en una comunidad rural. Informe preliminar. Rev Fac Odontol Buenos Aires 1985; 5(2): 15-22.

Carneiro AMO, Kolmogoroff IF, Silva AO. As políticas de saúde para a zona rural brasileira: o caso da saúde bucal de Brazilândia no Distrito Federal, Brasília, 1998 [on line]. [Monografia apresentada no Curso de Especialização em Saúde Coletiva - Faculdade de Ciências da Saúde da Universidade de Brasília. Disponível em: http://www.saudebucalcoletiva.unb.br [2001 maio 26]

Chabaribery D. Inovação e desigualdade no desenvolvimento da agricultura paulista. Piracicaba: Instituto de Economia Agrícola; 1999. 
Chen M, Andersen RM, Barmes DE, Leclercq M-H, Lyttle CS. Comparing oral health care systems: a second international collaborative study. Geneva:World Health Organization; 1997.

Chironga L, Manji F. Dental caries in 12-year-old urban and rural children in Zimbabwe. Community Dent Oral Epidemiol 1989; 17: 31-3.

Crowley SJ, Campain AC, Morgan MV. An economic evaluation of a publicly funded dental prevention programme in regional and rural Victoria: na extrapolates analysis. Community Dent Health 2000; 17: 145-51.

Diehnelt DE, Kiyak HA. Socioeconomic factors that affect international caries leves. Community Dent Oral Epidemiol 2001; 29: 226-33.

Dini EL, Vertuan V, Pincelli CAS. Condições bucais de escolares da área rural do Município de Araraquara-SP. Rev Odontol UNESP 1993; 22: 125-33.

El-Nadeef MAI, Adegbembo AO. The association of urbanisation with the prevalence of dental caries among schoolchildren in Nigeria new capital territory. Int Dent J 1998; 48: 44-49.

Fiske J, Waters RM. The benefit of dental care to an elderly population assessed using a sociodental measur of oral handicap. Br Dent J 1990; 168: 153-6. 
Freitas SFT. História social da cárie dentária. Bauru: EDUSC, 2001.

Frias AC. Estudo da confiabilidade do Levantamento Epidemiológico de Saúde

Bucal, Estado de São Paulo, 1998. São Paulo; 2000. [Dissertação de mestradoFaculdade de Saúde Pública USP]

Furtado A, Traebert JL, Marcenes WS. Prevalência de doenças bucais e necessidade de tratamento em Capão Alto, Santa Catarina. Rev ABO Nac 1999; 7: 226-30.

Garcia-Godoy F, et al. Periodontal treatment needs in 12-16-year-old children from Santo Domingo. Community Dent Oral Epidemiol 1986; 14: 250-252.

Garmonal JA, Lopes NJ, Aranda W. Periodontal conditions and treatment needs by CPITN in the 35-44 and 56=74 years old population in Santiago-Chile. Int Dent $\mathbf{J}$ 1998; 48: 96-103.

Gelbier S, Rpbinson PG. Dental public health. In: Ditels R, Mc Ewen J, Beaglehole $\mathrm{R}$, Tanaka $\mathrm{H}$, editors. Oxford textbook of public health: the pratice of public health. 4. ed. Oxford: Oxford University Press; 2002. v. 3, p. 1329-48.

Gruebbel AO. A mesurement of dental caries prevalence and treatment service for deciduos teeth. J Dent Res 1944; 23: 163. 
Hille AL. Contribuição para modelo de plano de saúde dental em área rural concentrada. Londrina; 1976. [Tese de doutorado - Faculdade de Odontologia da Universidade Estadual de Londrina].

[IBGE]. Fundação Instituto Brasileiro de Geografia e Estatística. Recenseamento geral da população: 2000. [on line] Disponível em: <URL: http://www.ibge.gov.br/censo/default.php> [2002 ago 2].

Irigoyen ME, Luengas IF, Yashine A, Mejia AM, Maupome G. Dental caries experience in Mexican schoolchildren from rural and urban communities. Int Dent $\mathbf{J}$ $2000 ; 50: 41-5$.

Jamel HA, Sheiham A, Watt RG, Cowell CR. Sweet preference, consumption of sweet tea and dental caries; studies in urban and rural Iraqi populations. Int Dent $\mathbf{J}$ 1997; 47: 213-7.

Jenny J, Proshek JM. Visibility and prestige of occupations and the importance of dental appearance. Can Dent Assoc J 1986; 52: 987-9.

Jones CM, Taylor GO, Whittle JG, Evans D, Trotter DP. Water fluoridation, tooth decay in 5 year olds and social deprivation measured by the Jarman score:analysis of data from British dental surveys. BMJ 1997; 315:514-7. 
Johnson RA, Wichern DW. Applied multivariate statistical analysis. Upper Saddle River, NJ, USA: Prentice Hall, 1998.

Junqueira SR. Financiamento da saúde, indicadores sociais e recursos odontológicos dos municípios do estado de São Paulo no final do século XX. São Paulo; 2001. [Dissertação de Mestrado - Faculdade de Odontologia da USP].

Klein H, Palmer CE. Dental caries X. a procedures for the recording and statistical processing of dental examination findings. Journal of Dental Research 1940; 10: 243-256.

Kuusela S, Honkala E, Kannas L, Tynjala J, Wold B. Oral hygiene habits of 11-yearold schoolchildren in 22 European countries and Canada in 1993/94. J Dent Res 1997; 76: 1602-9.

Leake JL, Otchere DF, Davey KW, Bedford WR, Mc Intyre DO. The dental health of 12 year-old children in Dominica: a report of a survey using WHO methods. J Can Dent Assoc 1990; 56: 1025-8.

Löe H, Theilade E, Jensen SB. Experimental gengivits in man. J Periodontol 1965; $36: 177-87$

Maltz M, Silva BB. Relação entre cárie, gengivite e fluorose e níveis socioeconômicos em escolares. Rev Saúde Pública 2001; 32(2): 170-76. 
Manji F, Baelum V, Fejerskov O. Tooth mortality in an adult rural population in Kenya. J Dent Res 1988; 67: 496-500.

Marcantonio Junior E, Santos FA. Avaliação das condições e necessidades de tratamento periodontal em escolares da zona rural da região noroeste do estado de São Paulo. Rev Odontol UNESP 1998; 27(2): 449-458.

Marques DE, Rink MCM, Loureiro RMT, Silva VC. Levantamento epidemiológico de cárie dentária na zona rural de Uberlândia, Minas Gerais; contribuição para um modelo de programa de saúde bucal. R Cent Ciênc Bioméd Univ Fed Uberlândia $1986 ; 2: 33-8$

Martinelli Júnior O. O complexo agroindustrial no Brasil: um estudo sobre a agroindústria citrícola no Estado de São Paulo. São Paulo: USP/FEA; 1987.

Mattila ML, Rautava P, Sillanpa M, Paunio P. Caries in five-year-old children and associations with family-related factors. J Dent Res 2000; 79: 875-81.

Mello TRC, Antunes JLF. Prevalência de cárie dentária em escolares da região rural de Itapetininga, São Paulo, Brasil. Cad Saúde Pública 2004; 20(3):829-835.

Milsom KM, Rijal K, Lennon MA. Oral health status of 12-year-old children in Nepal in 1994. Int Dent J 1997; 47: 88-93. 
Moalic É, Zerilli A, Capo-Chichi S, Apovi G. Oral and dental health of a population of school children from the Zou region of Benin (1998). Santé 1999; 9(5): 273-6.

Morgenstern H. Ecologic studies In: Rothman KJ, Greenland S. Modern epidemiology. Philadelphia: Lippincott-Raven Publishers; 1998. p. 459-80.

Morse RM. Formação histórica de São Paulo (de comunidade à metrópole). São Paulo: Difusão Européia do Livro; 1970.

Mumghamba EGS, Markkanen HA, Honkala E. Periodontal status and treatment needs in rural area of Ukonga, Tanzania. Int Dent $\mathbf{J}$ 1996; 46:156-60.

Nadanovsky P, Sheiham A. Relative contribution of dental services to the changes in caries levels of 12-year-old children in industrialized countries in the 1970s and early 1980s. Community Dent Oral Epidemiol 1995; 23: 331-339.

Nalweyiso N, Busingye J, Whitworth J, Robinson PG. Dental treatment needs of children in rural subcounty of Uganda. Int Journ of Paed Dent 2004; 14:27-33.

Narvai PC, Frazão P, Castellanos RA. Declínio na experiência de cárie em dentes permanentes de escolares brasileiros no final do século XX. Odontol Soc 1999; 1: $25-9$. 
Ntabaye MK, Scheutz F, Poulsen S. Patient satisfaction with emergency oral health care in rural Tanzania. Community Dent Oral Epidemiol 1998; 26: 289-95.

Pallos D, Loberto JCS, Cortelli JR, Cortelli SC, Souza DM, Ricardo LH. Periodontal disease in a rural community in Minas Gerais, Brazil. Braz J Oral Sci 2005; 4(2): 659-663.

Peres MA, Narvai PC, Calvo MCM. Prevalência de cárie dentária em crianças aos 12 anos de idade, em localidades do Estado de São Paulo, Brasil, período 1990-1995. Rev Saúde Pública 1997; 31: 594-600.

Peres MA, Latorre MRDO, Sheiham A, Peres KGA, Barros FC, Hernandez PG et al. Determinantes sociais e biológicos da cárie dentária em crianças de 6 anos de idade: um estudo transversal aninhado numa coorte de nascidos vivos no Sul do Brasil. Rev Bras Epidemiol 2003; 6: 293-304.

Peres MA, Fernandes LS, Peres KG. Inequality of water fluoridation in Southern Brazil - the inverse equity hypothesis revisited. Soc Sci Med 2004; 58:1181-9.

Peres MA, Latorre MRDO, Sheiham A, Peres KGA, Barros FC, Hernandez PG, et al. Social and biological early life influences on severity of dental caries in children aged 6 years. Community Dent Oral Epidemiol 2005; 33:53-63. 
Peres MA, Antunes JLF. O método epidemiológico de investigação e sua contribuição para a saúde bucal. In: Antunes JLF, Peres MA, editores. Epidemiologia da Saúde Bucal. Rio de Janeiro: Guanabara; 2006, p.011-18.

Peres KGA, Bastos JRM, Latorre MRDO. Severidade de cárie em crianças e relação com aspectos sociais e comportamentais. Rev Saúde Pública 2000; 34(4): 402-408.

Petersen PE, Mzee MO. Oral health profile of schoolchildren, mothers ans schoolteachers in Zanzibar. Community Dent Health 1998; 15: 265-62.

Petersen PE. The world oral health report 2003: continuous improvement of oral health in the $21^{\text {st }}$ century - the approach of the WHO Global Oral Health Programme. Community Dent Oral Epidemiol 2003; 31(1): 3-24.

Petroni MTS. A lavoura canavieira em São Paulo: expansão e declínio (17651851). São Paulo: Difusão Européia do Livro; 1968.

Pinto VG. Características do subsistema público federal de prestação de serviços em odontologia. São Paulo; 1977 [Dissertação de Mestrado - Faculdade de Saúde Pública da USP].

Pinto VG. Saúde Bucal Coletiva $4^{\mathrm{a}}$. ed. São Paulo: Santos; 2000. 
[PNUD] Programa das Nações Unidas para o Desenvolvimento. Instituto de Pesquisa Econômica Aplicada. Fundação João Pinheiro. Fundação Instituto Brasileiro de Geografia e Estatística. Atlas do Desenvolvimento Humano no Brasil. Brasília (DF); 1998.

Ramos P. Um estudo da evolução e da estrutura da agroindústria canavieira do estado de São Paulo (1930-1982). São Paulo; 1983. [Dissertação de Mestrado Fundação Getúlio Vargas].

Sampaio FC, Hossain NA, Von der Fehr FR, Ameberg P. Dental caries and sugar intake of children from rural areas with different water fluoride leves in Paraíba, Brazil. Community Dent Oral Epidemiol 2000; 28: 307-13.

SATHANANTHAN K, VOS T, BANGO G. DENTAL CARIES, FLUORIDE LEVELS AND ORAL HYGIENE PRACTICES OF SCHOOL CHILDREN IN MATEBELAND SOUTH, ZIMBABWE. COMMUNITY DENT ORAL EPIDEMIOL 1996; 24: 21-4.

Schou L, Uitenbroek D. Social and behavioural indicators of caries experience in 5year-old children. Community Dent Oral Epidemiol 1995; 23: 276-81.

[SEADE]. Fundação Sistema Estadual de Análise de Dados. Reestruturação produtiva e requisitos para a formação profissional no Estado de São Paulo. [on line] Disponível em:

<URL: http:॥www.mec.gov.br/semtec/proep/paer/estmec/sp > [2003 ago 10]. 
[SEADE]. Fundação Sistema Estadual de Análise de Dados. Base Unificada de Nascimentos e Óbitos da Fundação Seade, Secretaria de Estado da Saúde e Secretarias Municipais da Saúde. [on line] Disponível em:

<URL:http://www.seade.gov.br/produtos/spdemog/PDF/tmi municipiosESP 1995 2005.pdf [2006 abril 10].

Silva JG, Balsadi OV, Bolliger FP, Borin MR, Paro MR. O rural paulista muito além do agrícola e do agrário. S. Paulo Perspect 1996; 10: 55-64.

Silva JG, Grossi MD, Campanhola C. O que há de realmente novo no rural brasileiro. Cad de Ciênc \& Tec 2002; 19(1): 37-67. Disponível em: <URL:http://atlas.sct.embrapa.br/pdf/cct/v19/cc19n102.pdf\#search='rural\%20grazian o\%20silva $\% 20$ brasileiro $\% 20$ produ $\% \mathrm{C} 3 \% \mathrm{~A} 7 \mathrm{ao} \% 20$ renda $>$ [2006 jun 02].

Snijders TAB, Bosker RJ. Multilevel analysis: an introduction to basic and advanced multilevel modeling. London: Sage Publications; 2003.

Sofola OO, Shaba OP, Jeboda SO. Oral hygiene and periodontal treatment needs of urban school children comparade with that of rural chool children in Lagos State, Nigeria. Odontostomatol Trop 2003; 26(101):25-9.

Teixeira ACS, Rocha PLOM, Zanetti CHG. A zona rural de Planaltina e a proposta de um modelo viável de atenção em saúde bucal. [on line]. Brasília (DF); 2000. [Monografia apresentada no Curso de Especialização em Saúde Coletiva 
- Faculdade de Ciências da Saúde da Universidade de Brasília] Disponível em: <URL: http://www.saudebucalcoletiva.unb.br> [2001 maio 26].

Thylstrup A, Fejerskov O. Cariologia clínica. São Paulo: Ed. Santos, 2001.

Traebert JL, Peres MA, Galesso ER, Zabot NE, Mercenes W. Prevalência e severidade da cárie dentária em escolares de seis a doze anos de idade. Rev Saúde Pública 2001; 35(3):283-8.

[USP] Universidade de São Paulo. Faculdade de Saúde Pública. Núcleo de Estudos e Pesquisas de Sistemas de Saúde. Levantamento epidemiológico em saúde bucal: Estado de São Paulo, 1998. São Paulo; 1999.

Waldman EA, Silva LJ, Monteiro CA. Trajetória das doenças infecciosas: da eliminação da poliomielite à reintrodução da cólera. In: Monteiro CA. Velhos e novos males da saúde no Brasil: a evolução do país e de suas doenças. 2. ed. São Paulo: Hucitec, Nupens/USP; 2000. p. 195-244.

Walsh J. International patterns of oral health care - the example of New Zealand. $\mathbf{N} \mathbf{Z}$ Dent J 1970; 66: 143-52. 
Watt RG. Strategies and approaches in oral disease prevention and health promotion.

Bulletin of the World Health Org 2005; 83(9): 711-18.

[WHO] World Health Organization. Oral health surveys: basic methods. 4. ed. Geneva: WHO; 1997. 